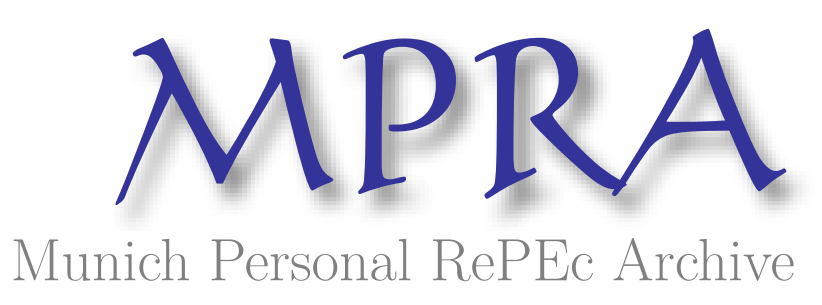

Rotterdam vs Almost Ideal Models: Will the Best Demand Specification Please Stand Up?

Barnett, William A. and Seck, Ousmane

6 February 2006

Online at https://mpra.ub.uni-muenchen.de/417/

MPRA Paper No. 417, posted 12 Oct 2006 UTC 


\title{
Rotterdam Model versus Almost Ideal Demand System: Will the Best Specification Please Stand Up?
}

\author{
William A. Barnett \\ University of Kansas \\ Ousmane Seck \\ California State University at Fullerton
}

May 18, 2007

\begin{abstract}
Among the many demand specifications in the literature, the Rotterdam model and the Almost Ideal Demand System (AIDS) have particularly long histories, have been highly developed, and are often applied in consumer demand systems modeling. Using Monte Carlo techniques, we seek to determine which model performs best in terms of its ability to recover the true elasticities of demand.

In applications, the AIDS model has been used in linearized form, where the linearization is accomplished by the choice of a price index to replace the price aggregator function that is within the full nonlinear model. Since the Rotterdam model also is linear in a very similar form, the comparison of the Rotterdam model and the AIDS model has been the subject of much speculation in the literature. We derive the formulas for the AIDS model's elasticities, when the Törnqvist or two modified versions of the Stone price index are used to linearize the model. We not only compare the resulting linearized AIDS model with the Rotterdam model, but also with the full nonlinear AIDS.
\end{abstract}

Keywords: Rotterdam Model, Almost Ideal Demand System, consumer demand system, Monte Carlo study, flexible functional forms

JEL Classifications: C3, E41, G12, C43, C22 


\section{Introduction}

Estimation of demand functions consistent with economic theory has been a highly published area in the last forty years. The majority of the currently influential papers have appeared following the adoption of flexible functional forms, which rely heavily on duality theory. The Generalized Leontief (Diewert, 1971), the Translog (Christensen et al., 1975), the Rotterdam (Theil, 1965, 1975; Barten, 1964, 1968, 1977), and the Almost Ideal Demand System or AIDS (Deaton and Muellbauer, 1980a,b) are examples of popular demand models. Their functional forms are locally flexible, in the sense that they do not put a priori restrictions on the possible elasticities at a point. These models possess enough parameters to approximate any elasticities at a given point. But locally flexible functional forms often exhibit small regular regions consistent with microeconomic theory. As a result, a number of alternative flexible functional forms with larger regular regions have been developed. Examples include the Quadratic AIDS model (QUAIDS) (Banks et al., 1997), the Laurent model (Barnett, 1983, 1985; Barnett and Lee 1985; Barnett et al. 1985, 1987), and the Generalized Exponential Form (G.E.F) (Cooper and McLaren, 1996).

As an alternative to locally flexible functional forms, a seminonparametric approach has been used to specify globally flexible functional forms, having enough parameters to approach arbitrary elasticities at all points asymptotically. Gallant (1981) proposed the Fourier model, using the $\sin / \cos$ series expansions. The Asymptotically Ideal Model (Barnett and Jonas, 1983; Barnett and Yue, 1998) applies Gallant's global approach to the Müntz-Szatz series expansion.

Although many functional forms are available, economic theory does not answer the question of which specification is the best to choose in estimating demand functions using a given data set. This is ambiguity is unavoidable, since the space of neoclassical functions cannot be spanned by any model having a finite number of parameters. Different approaches for comparison have been proposed in the literature.

An elementary approach consists of estimating different specifications of demand functions with a given data set and selecting the one that has the best goodness of fit statistics (Berndt, Darrough and Diewert, 1977; Fisher, Fleissig and Serletis, 2001). A second approach uses the fact that the properties of demand functions derived from neoclassical preferences are known only in the region within which the functions satisfy theoretical regularity conditions. Knowing the location and size of the regular region can help support the choice of one functional form over another (Caves and Christensen, 1980; Barnett and Lee, 1985; Barnett et al., 1985). A third 
approach uses a Monte Carlo study to explore accuracy of the demand model, when the true elasticities of substitutions are known (Barnett and Choi, 1989).

In applied microeconomics, the AIDS and the Rotterdam models are frequently used, since each can be estimated in a linearized form with theoretical restrictions easily imposed and tested. Earlier linear demand models possessed awkward connections with economic theory that tended to be difficult to impose or test. Studies that compare these two models have been few, even though Deaton and Muellbauer (1980a) pointed out the striking similarity between these two models. In particular, the AIDS model with linearizing price index (LA-AIDS) can be rewritten in a first difference form, such that LA-AIDS has the same dependent variables as the Rotterdam model in its absolute price version. Alston and Chalfant (1993) developed a statistical test for comparing the LA-AIDS model versus the Rotterdam model with real data, but no Monte Carlo comparisons of the two models have ever been published.

Although current computer capabilities permit nonlinear estimation, the linear approximated AIDS model is still widely used in the place of the full AIDS. In addition, no Monte Carlo study has ever compared the linearized AIDS with the full AIDS model in their ability correctly to approximate known elasticities of substitution. ${ }^{1}$ We conduct a Monte Carlo study comparing the linearized AIDS model, the full AIDS model, and the Rotterdam model.

\section{Elasticities of substitution}

The concept of elasticity of substitution between two factors was first introduced by Hicks (1932) as a tool for analyzing changes in the distribution of income between capital and labor, when factor price ratios change. Because of its ability to classify goods as complements or substitutes and its interpretation as curvature of isoquants, elasticities of substitution carry much information.

Allen and Hicks (1934) proposed generalizations to more than two factors. The generalizations are known as the Hicks's elasticity of substitution (HES) and a version of the current Allen-Uzawa elasticity of substitution (AUES). The HES is no longer used, since it ignores substitution among factors when relative prices change. Allen (1938) and Uzawa (1962) improved

\footnotetext{
${ }^{1}$ Alston, Foster, and Green (1994) generated data with price elasticities consistent with the nonlinear AIDS formulas, and tested the ability of four linear approximate AIDS to recover the known elasticities.
} 
upon the second generalization, and that improved formula is now the one known as the AUES, having formula is given by:

$$
\begin{aligned}
\sigma_{i j}^{A U} & =-\frac{\partial \log \left[x_{i}(\mathbf{p}, U) / x_{j}(\mathbf{p}, U)\right]}{\partial \log \left[p_{i} / p_{j}\right]} \\
& =\frac{C(\mathbf{p}, U) C_{i j}(\mathbf{p}, U)}{C_{i}(\mathbf{p}, U) C_{j}(\mathbf{p}, U)} \\
& =\frac{\varepsilon_{i j}(\mathbf{p}, U)}{w_{j}(\mathbf{p}, U)}
\end{aligned}
$$

where the subscripts on the cost function, $C$, indicate differentiation with respect to the indicated prices, and $\varepsilon_{i j}(\mathbf{p}, U)=\partial \log x_{i}(\mathbf{p}, U) / \partial \log p_{j}$ is the Hicksian elasticity of demand for good $i$ with respect to the price of good $j$, while $w_{j}(\mathbf{p}, U)$ is the expenditure share of good $j$. The vector of $\mathrm{n}$ prices is $\mathbf{p}$ and $\mathrm{U}$ is the utility level.

Another generalization of the two-input elasticity, known as the Morishima elasticity of substitution, was proposed by Morishima (1967) and advocated by Blackorby and Russell (1981, 1989). It is given by

$$
\begin{aligned}
\sigma_{i j}^{M} & =-\frac{\left.\partial \log \left[x_{i}(\mathbf{p}, U) / x_{j}(\mathbf{p}, U)\right)\right]}{\partial \log \left[p_{i} / p_{j}\right]} \\
& =\frac{p_{i} C_{i j}(\mathbf{p}, U)}{C_{j}(\mathbf{p}, U)}-\frac{p_{i} C_{i i}(\mathbf{p}, U)}{C_{i}(\mathbf{p}, U)} \\
& =\varepsilon_{i j}(\mathbf{p}, U)-\varepsilon_{i i}(\mathbf{p}, U),
\end{aligned}
$$

where the last line of the equation is based upon normalization of the price of good $j$ to unity. In accordance with the usual preference in the literature, we choose to use the Allen-Uzawa elasticity of substitution (AUES).

With Hicksian demand functions, we compute the AUES directly. But when we estimate the Marshallian demand functions, we recover the elasticities of substitution from the Slutsky 
equation in its elasticities form, $\varepsilon_{i j}(\mathbf{p}, U)=\varepsilon_{i j}(\mathbf{p}, m)+w_{j} e_{i}(\mathbf{p}, m)$, where $e_{i}$ is the income elasticity of the demand for good $i, m$ is total consumption expenditure, and $\varepsilon_{i j}(\mathbf{p}, m)$ is the uncompensated cross-price elasticity for good $i$.

\section{Model description}

We briefly introduce the Rotterdam model in its absolute price version and the AIDS model. We provide the theoretical constraints that must be satisfied for the models to be consistent with consumer theory. We also provide the formulas for the various elasticities of demand that we use for those models.

\subsection{The absolute price version of the Rotterdam model ${ }^{2}$}

The absolute price version of the model is:

$$
\bar{w}_{i t} D q_{i t}=\mu_{i} D Q_{t}+\sum_{j=1}^{n} \pi_{i j} D p_{j t}+v_{i t}
$$

where $\bar{w}_{i t}=\frac{1}{2}\left(w_{i, t}+w_{i, t-1}\right)$ is the average budget share of good i between the periods $t-1$ and $t$, $v_{\text {it }}$ is a stochastic disturbance, and $D Q_{t}=\sum_{i=1}^{n} \bar{w}_{i t} D q_{i t}$ can be shown is the log-change in real income.

The model is estimated subject to the following theoretical restrictions:

$$
\begin{aligned}
& \sum_{i=1}^{n} \mu_{i}=1 \text { for Engel aggregation } \\
& \sum_{i=1}^{n} \pi_{i j}=0 \text { for linear homogeneity, }
\end{aligned}
$$

and symmetry, $\pi_{i j}=\pi_{j i}$. With this model, the Slutsky substitution matrix is $\left[\pi_{i j}\right]$.

When the linear homogeneity restriction is imposed, each equation has $n$ unknown parameters and $n$ independent variables. The system can be estimated with one equation deleted after imposing Engel aggregation and symmetry. If equation $n$ is deleted, its parameters can be recovered by summing the $n-1$ equations and by using the constraints of homogeneity, Engel aggregation, and symmetry. The imposition of theoretical restrictions on the model has the virtue of reducing the number of unknown parameters and improving the efficiency of the estimation.

\footnotetext{
${ }^{2}$ See Barten (1964), Barnett (1979), and Theil (1965, 1975a,b) for the derivations.
} 
Equation (3) subject to the homogeneity restriction becomes

$$
\bar{w}_{i t} D q_{i t}=\mu_{i} D Q_{t}+\sum_{j=1}^{n-1} \pi_{i j}\left(D p_{j t}-D p_{n t}\right)+v_{i t} .
$$

Estimation can be subject to the restriction of symmetry. Theory also requires negative semidefiniteness of the Slutsky matrix; but, rather than being imposed, that restriction usually is just checked at the point of approximation. With imposed linear homogeneity restriction, the rank of $\left[\pi_{i j}\right]$ becomes $n-1$. The condition for this matrix to be negative semi-definite in the three-good case is

$$
\pi_{11}<0 \quad \text { and } \quad \operatorname{det}\left(\left[\begin{array}{ll}
\pi_{11} & \pi_{12} \\
\pi_{21} & \pi_{22}
\end{array}\right]\right)=\pi_{11} \pi_{22}-\pi_{12} \pi_{21}>0
$$

These restrictions could be imposed during estimation. But as the number of goods increases, that imposition becomes computationally burdensome and hence rarely is imposed but rather just checked after estimation. In our comparisons of the Rotterdam with the AIDS model, we report the percent of replications producing non-violation of the negative semi-definiteness as an indicator of regularity. In particular, regularity percentage is defined in our results as the percent of non-violations of negative semi-definiteness.

\subsection{The full AIDS (PIGLOG) model}

The AIDS model in budget shares is

$$
w_{i}=\alpha_{i}+\sum_{k} \gamma_{i k} \log p_{k}+\beta_{i} \log \left(\frac{m}{P}\right),
$$

where the price deflator of the logarithm of income is

$$
\log P=\alpha_{0}+\sum_{k} \alpha_{k} \log p_{k}+\frac{1}{2} \sum_{k} \sum_{j} \gamma_{k j}^{*} \log p_{k} \log p_{j}
$$

and $\gamma_{i k}=\frac{1}{2}\left(\gamma_{i k}^{*}+\gamma_{k i}^{*}\right)$.

The restrictions on the demand functions are deduced from the cost function, using Shephard's duality lemma. The following are the resulting conditions imposed during estimation of the constrained model:

$$
\sum_{i=1}^{n} \alpha_{i}=1 \text { for adding up, }
$$




$$
\begin{gathered}
\sum_{i=1}^{n} \gamma_{i j}^{*}=0 \text { and } \sum_{i=1}^{n} \beta_{i}=0 \text { for linear homogeneity, } \\
\gamma_{i j}^{*}=\gamma_{j i}^{*} \text { for symmetry. }
\end{gathered}
$$

Equation (8) can be interpreted as a Marshallian or uncompensated demand function in budget shares. The Hicksian price elasticities of good $i$ with respect to good $j$ can be derived from the Marshallian price elasticities by using the Slutsky equation in elasticities. The expression for the Marshallian price elasticity becomes

$$
\varepsilon_{i j}^{M}=-\delta_{i j}+\frac{1}{w_{i}}\left[\gamma_{i j}-\beta_{i}\left(\alpha_{j}+\sum_{k} \gamma_{k j} \log p_{k}\right)\right],
$$

where $\delta_{i j}$ is the Kronecker delta, defined as:

$$
\begin{aligned}
\delta_{i j} & =1 \quad \text { if } i=j, \\
& =0 \quad \text { otherwise }
\end{aligned}
$$

while the income elasticity for good $i$ is

$$
\eta_{i}=1+\frac{\beta_{i}}{w_{i}} .
$$

Unlike the Rotterdam model, the AIDS model permits testing negative semi-definiteness of the Slutsky matrix at each data point. Using the Slutsky equation in terms of elasticities and the adding-up restriction, we find that the sum of Hicksian elasticities will seldom equal zero, where that sum is

$$
\sum_{i=1}^{n} \varepsilon_{i j}^{H}=-1+n w_{j}+\sum_{i=1}^{n}\left(\gamma_{i j}+w_{j} \beta_{i} / w_{i}\right)
$$

Hence the Slutsky matrix is negative semi-definite, if

$$
\varepsilon_{11}^{H}<0 \text { and } \operatorname{det}\left[\begin{array}{cc}
\varepsilon_{11}^{H} & \varepsilon_{12}^{H} \\
\varepsilon_{21}^{H} & \varepsilon_{22}^{H}
\end{array}\right]=\varepsilon_{11}^{H} \varepsilon_{22}^{H}-\varepsilon_{21}^{H} \varepsilon_{12}^{H}>0,
$$

where $\varepsilon_{i j}^{H}$ is the Hicksian elasticity for good $i$ with respect to the price of good $j$. Equation (16) for the AIDS model is analogous to equation (7) for the Rotterdam model and can be used to compute an upper bound on the percent of non-violations of negative semi-definiteness of the Slutsky matrix 


\subsection{The linear approximation of the AIDS model: LA-AIDS}

In applications, the nonlinearity of the AIDS model is usually viewed as a technical problem to be circumvent by a linearizing approximation to income's price deflator (9). ${ }^{3}$ In fact in the original literature on this model, the model was not called AIDS until after linearization. The fully nonlinear model described in section 3.2 above was called PIGLOG. Deaton and Muellbauer (1980a,b) suggest Stone's price index. When linearized by the use of Stone's index, PIGLOG was named the almost ideal demand system (AIDS) by Deaton and Muellbauer. Stone's geometric price index is given by

$$
P=\prod_{j=1}^{n} p_{j}^{w_{j}}
$$

Since we are calling PIGLOG the AIDS model, even in its fully nonlinear form, we use the designation LA-AIDS (Linear approximated AIDS) to designate the special cases of PIGLOG produced by linearization by Stone's index and by other linearizing price indexes that we consider. Estimation of the resulting LA-AIDS model has a potential, but usually overlooked, simultaneity bias problem, because the expenditure share $w_{i}$ is on both sides of the demand function for good $i$. Another issue with the use of Stone's index to linearize the model is that the simplification in estimation of LA-AIDS is offset by difficulties in deriving the elasticities. We compute the correct elasticities using Green and Alston (1990).

The Marshallian price elasticities, expressed in expenditure share form, are

$$
\varepsilon_{i j}=\frac{\partial \log q_{i}}{\partial \log p_{j}}=-\delta_{i j}+\frac{\partial \log w_{i}}{\partial \log p_{j}}=-\delta_{i j}+\frac{1}{w_{i}} \frac{\partial w_{j}}{\partial \log p_{j}},
$$

where again, as in (14),

$$
\delta_{i j} \text { is the Kronecker delta, }
$$

and the income elasticities are

$$
\frac{\partial \log q_{i}}{\partial \log m}=1+\frac{\partial \log w_{i}}{\partial \log m}=1+\frac{1}{w_{i}} \frac{\partial w_{i}}{\partial \log m} .
$$

Applying (18) to the demand functions (8) yields

$$
\varepsilon_{i j}=-\delta_{i j}+\frac{1}{w_{i}}\left(\gamma_{i j}-\beta_{i} \frac{\partial \log P}{\partial \log p_{i}}\right) .
$$

\footnotetext{
${ }^{3}$ See, e.g., Alston et al (1994).
} 
If we differentiate the logarithm of Stone's price index with respect to the logarithm of the price of good $j$ and use (18), we have

$$
\frac{\partial \log P}{\partial \log p_{j}}=w_{j}+\sum_{k} w_{k} \log p_{k} \frac{\partial \log w_{k}}{\partial \log p_{j}} .
$$

If we substitute (22) into (21), the expression for the Marshallian price elasticity becomes

$$
\varepsilon_{i j}=-\delta_{i j}+\frac{\gamma_{i j}}{w_{i j}}-\frac{\beta_{i}}{w_{i}}\left[w_{i}+\sum_{k} w_{k} \log p_{k}\left(\varepsilon_{k j}+\delta_{k j}\right)\right] .
$$

The elasticity of good $i$ with respect to the price of good $j$ is a function of all price elasticities. Equation (23) is a system of $n^{2}$ equations with $n^{2}$ unknown parameters. In matrix form, equation (23) can be written as

$$
\mathbf{E}=\mathbf{A}-\mathbf{k c}^{\prime}(\mathbf{E}+\mathbf{I})
$$

where $\mathbf{E}=\left[\varepsilon_{i j}\right]$ and $\mathbf{A}=\left[a_{i j}\right]$ are $n \times n$ matrices with $\mathbf{E}$ being the matrix of elasticities and with $a_{i j}=-\delta_{i j}+\gamma_{i j} / \varpi_{i}-\beta_{i} w_{j} / w_{i}$. The column vector $\mathbf{c}=\left[c_{1}, c_{2}, \ldots, c_{n}\right]^{\prime}$ has elements $c_{j}=w_{j} \log p_{j}$, the vector $\mathbf{k}=\left[k_{1}, k_{2}, \ldots, k_{n}\right]^{\prime}$ has elements $k_{i}=\beta_{i} / w_{i}$, and $\mathbf{I}$ is the identity matrix.

Solving (24) for $\mathbf{E}$ yields

$$
\mathbf{E}=\left[\mathbf{k} \mathbf{c}^{\prime}+\mathbf{I}\right]^{-1}[\mathbf{A}+\mathbf{I}]-\mathbf{I} .
$$

The income elasticities from the LA-AIDS are different from (15). Applying (20) to (8) and using Stone's price index, we can derive the income elasticity in budget share form from

$$
\eta_{i}=\frac{\partial \log q_{i}}{\partial \log m}=1+\frac{1}{w_{i}} \frac{\partial w_{i}}{\partial \log m} .
$$

Using the demand for good $i$ in budget share (8), the partial derivative with respect to income is

$$
\frac{\partial w_{i}}{\partial \log m}=\beta_{i}-\beta_{i} \frac{\partial \log P}{\partial \log m}
$$

The derivative of the Stone's price index in (27) can be written as

$$
\frac{\partial \log P}{\partial \log m}=\sum_{j} \log p_{j} \frac{\partial w_{j}}{\partial \log m}=\sum_{j} w_{i} \log p_{j}\left(\eta_{j}-1\right) .
$$

Hence, the income elasticity of good $i$ is related to the income elasticities of all other goods by the following expression 


$$
\eta_{i}=1+\frac{\beta_{i}}{w_{i}}\left[1-\sum_{j} w_{j} \log p_{i}\left(\eta_{j}-1\right)\right]
$$

Equation (29) can be written in vector form as

$$
\mathbf{n}=\mathbf{k}-\mathbf{k} \mathbf{c}^{\prime} \mathbf{n},
$$

where $\mathbf{k}$ and $\mathbf{c}$ are as defined in (24), and $\mathbf{n}$ is an $\mathbf{n}$-dimensional column vector having elements $n_{i}=\eta_{i}-1$. Solving (30) for $\mathbf{n}$ yields the following expression

$$
\mathbf{n}=\left[\mathbf{I}+\mathbf{k c}^{\prime}\right]^{-1} \mathbf{k}
$$

As in the nonlinear AIDS case, the Allen-Uzawa elasticities of substitution are derived from the Hicksian elasticities and the Slutsky equation.

\section{Non-homothetic preferences and the true elasticities}

The Leontief technology and the Arrow, Chenery, Minhas and Solow (1961) constant elasticity of substitution production function yield elasticity of substitution between two goods equal respectively to zero and a constant. Both of those early models have elasticities of substitution that are the same for all pairs of goods and do not vary as quantities vary. Even in the two good case, these models are defective, since decreasing marginal returns are associated with varying elasticities of substitution between the two goods.

The generalized-quadratic functional form (Kadiyala, 1972; Denny 1974) weakens those restrictive implications. That utility function is

$$
U\left(Q_{1}, Q_{2}, \ldots, Q_{n}\right)=A\left[\sum_{i=1}^{n} \sum_{j=1}^{n} a_{i j} Q_{i}^{\rho} Q_{j}^{\rho}\right]^{1 / 2 \rho}
$$

The following restrictions on the parameters guarantee that the utility function satisfies the regularity conditions of quasi-concavity and monotonicity:

$$
\rho<1 / 2 ; \quad \sum_{i=1}^{2} \sum_{j=1}^{2} a_{i j}=1 ; \quad a_{i j}>0 \text { for all } i, j ; \quad a_{i j}=a_{j i} \text { for all } i \neq j .
$$

The only restriction on the scaling parameter, $A$, is positivity. When $n=2$, the expression for the elasticity of substitution has a simple form given by

$$
\xi_{12}^{*}=\frac{1}{1-\rho+R}
$$


where

$$
R=-\rho \frac{a_{11} a_{22}-a_{12}^{2}}{\left(a_{11} Q^{-\rho}+a_{12}\right)\left(a_{12}+a_{22} Q^{\rho}\right)}
$$

and $Q=Q_{2} / Q_{1}$.

The utility function (32) is homothetic in $Q_{i}, \mathrm{i}=1, \ldots, \mathrm{n}$. Homotheticity implies that all income elasticities are unitary. The utility function can be transformed into a non-homothetic utility function by defining the quantities $Q_{i}$ to be supernumerary quantities, $Q_{i}=x_{i}-a_{i}$, with $x_{i}$ being the quantity of good $i$ and $a_{i}$ a constant.

To retain the simplicity of the two-good generalized quadratic, while introducing a third good, with the possibility of different elasticities of substitution between different pairs of goods, we adopt the weakly-separable-branch generalized-quadratic defined by (36). This model was originated by Barnett (1977) and called WS-branch. In adopting this model for our Monte Carlo study, we follow Barnett and Choi (1989). The resulting utility function in the 3-goods case is

$$
U\left(Q_{1}\left(x_{1}, x_{2}\right), Q_{2}\left(x_{3}\right)\right)=A\left[a_{11} Q_{1}^{2 \rho}+a_{12} Q_{1}^{\rho} Q_{2}^{\rho}+a_{22} Q_{2}^{2 \rho}\right]^{1 / 2 \rho},
$$

where $Q_{1}$ and $Q_{2}$ are aggregator functions defined as follows

$$
Q_{1}=Q_{1}\left(y_{1}, y_{2}\right)=B\left[b_{11} y_{1}^{2 \delta}+b_{12} y_{1}^{\delta} y_{2}^{\delta}+b_{22} y_{2}^{2 \delta}\right]^{1 / 2 \delta},
$$

with supernumerary quantities $y_{i}=x_{i}-a_{i}, i=1,2$ and with $Q_{2}=Q_{2}\left(x_{3}\right)=y_{3}=x_{3}-a_{3}$. The parameters are $A, B, a_{\mathrm{ij}}, b_{\mathrm{ij}}, \delta$, and $\rho$.

Parameter constraints similar to (33) are sufficient to ensure regularity of the aggregator function (37). The scaling parameters $A$ and $B$ in (36) and (37) produce monotonic transformations of the utility function, and hence $A$ and $B$ can be set equal to unity without loss of generality.

Dual to the quantity aggregator function, $Q_{1}\left(y_{1}, y_{2}\right)$, there exists a price aggregator function, $\mathrm{p}^{*}=P_{Q_{1}}$, such that the identity $Q_{1}\left(y_{1}, y_{2}\right) P_{Q_{1}}=\sum_{i=1}^{2} p_{i} y_{i}$ holds, whenever $\left(y_{1}, y_{2}\right)$ is the solution to $\min \sum_{i=1}^{2} p_{i} y_{i}$ subject to $Q_{1}\left(y_{1}, y_{2}\right)=k$, with $k$ a positive constant. The price index dual to the quantity aggregator function can be computed directly as the ratio between total expenditure on $y_{1}$ and $y_{2}$ and the quantity aggregate $Q_{1}$, in accordance with the well-known Fisher 
factor reversal test. The use of this exact price aggregate will have valuable implications in our simplification of the income elasticities formulas.

The relevant formulas for the elasticities can be derived from the usual partial derivatives of the demand functions with respect to prices and income. However, Barnett and Choi (1989) derived formulas from the income and prices elasticities and for the elasticities of substitution in a manner that benefits from the simplicity of the Allen-Uzawa elasticities of substitution. For $i \in\{1,2\}$ and $j=3$, Barnett and Choi found that the elasticity of substitution between $x_{i}$ and $x_{j}$ is

$$
\sigma_{12}=\frac{\xi_{12}^{*}}{1-\bar{p} a} \frac{\left(x_{j}-a_{j}\right)\left(x_{i}-a_{i}\right)}{x_{j} x_{i}},
$$

where $\xi_{12}^{*}$ is the elasticity of substitution between the exact aggregates $Q_{1}$ and $Q_{2}, \bar{p}$ is the vector of income normalized prices, $\bar{p}_{i}=p_{i} / m$, with "income" defined to mean total consumption expenditure, $m=\sum_{k=1}^{3} p_{k} x_{k}$. The income elasticities are given by

$$
\eta_{j}=\frac{1}{1-\bar{p} a} \frac{x_{j}-a_{j}}{x_{j}}, \quad \text { for } \quad j=1,2,3 \text {. }
$$

The supernumerary quantities $y_{1}$ and $y_{2}$ are weakly separable from $y_{3}$. Therefore the elasticity of substitution between $y_{1}$ and $y_{2}$, and hence between $x_{1}$ and $x_{2}$, is calculated using the aggregator function $Q_{1}$ defined by equation (37). Therefore the elasticity of substitution between $y_{1}$ and $y_{2}$ can be written as

$$
\xi_{12}=\frac{1}{1-\delta+R^{\prime}}
$$

where

$$
R^{\prime}=-\delta^{*} \frac{b_{11} b_{22}-b_{12}^{2}}{\left(b_{11} y^{-\delta}+b_{12}\right)\left(b_{12}+b_{22} y^{\delta}\right)},
$$

and $y=y_{2} / y_{1}$. The elasticity of substitution between $x_{1}$ and $x_{2}$ is

$$
\sigma_{12}=\frac{\xi_{12}}{1-\bar{p} a} \frac{\left(x_{1}-a_{1}\right)\left(x_{2}-a_{2}\right)}{x_{1} x_{2}} .
$$


The compensated cross-price elasticities are derived from the Allen-Uzawa elasticities of substitution by using their relationship with cross-price elasticities and expenditure shares:

$$
\pi_{i j}^{H}=\sigma_{i j} w_{j}
$$

where $\pi_{i j}^{H}$ is the Hicksian elasticity of the demand for good $i$ with respect to the price of good $j$ and where the expenditure shares are $w_{j}=p_{j} x_{j} / \sum_{k} p_{k} x_{k}$.

\section{Data-generation process}

The data are generated for three goods from the generalized quadratic utility function, defined by equations (36) and (37). Appendix A1 describes the selection of the parameters and the median data point at which we set the true elasticities. The data generation then proceeded in accordance with the steps described below and illustrated by figure 1 .

Step 1: Generate a set of three autoregressive one processes containing 61 observations on each. The three generated variables are the quantities $y_{1}, y_{2}$ and total expenditure, $m_{1}^{4}$, on those two supernumerary quantities within the 2-goods branch of the utility tree.

Step 2: Set, in each of the nine cases, the parameters, $\left(b_{11}, b_{12}, b_{22}, a_{1}, a_{2}, \delta\right)$ of the inner aggregator function, $Q_{1}$, defined by equation (37), to attain at the median income the preselected values for the elasticities of $Q_{1}$. In the tables and discussion, the nine cases are called cases 1,2 , ...., 9. The parameter $B$ is normalized to equal 1.0 .

Step 3: Solve for the price time series, $p_{1}$ and $p_{2}$, from the first order conditions for totalexpenditure constrained maximization of $Q_{1}$, defined by equation (37).

Step 4: Compute the aggregate $Q_{1}$ and the dual price index $p^{*}$ that satisfy the Fisher factor reversal test. ${ }^{5}$

Step 5: Generate the supernumerary quantity $Q_{2}{ }^{6}$ following an autoregressive one time series containing 61 observations on the supernumerary quantity $\mathrm{Q}_{2}$.

\footnotetext{
${ }^{4}$ The three time series are as follows : $y_{1, t}=3+.89 y_{1, t-1}+e r_{1, t} ; y_{2, t}=5+.79 y_{2, t-1}+e r_{2, t} ;$ and $m_{1, t}=125+.865 m_{1, t-1}+$ $e r_{3, t}$, where $e r_{1}, e r_{2}, e r_{3}$ are disturbances that are independently and normally distributed with mean zero and variance 1.

${ }^{5}$ Fisher's factor reversal test assures that total expenditure, $\mathrm{m}_{1}$, on the components, $y_{1}$ and $y_{2}$, of the aggregate equals expenditure on the aggregate, $Q_{1}$, at its dual price $p^{*}$.

${ }^{6}$ The time series $Q_{2, t}=\mathrm{y}_{2, \mathrm{t}}=9+.9 y_{2, t-1}+e r_{4, t}$, where the $e r_{4}$ are disturbances that are independently and normally distributed with mean zero and variance 1 .
} 
Step 6: Set the parameters, $\left(a_{3}, a_{11}, a_{12}, a_{22}, \rho\right)$ of the outer utility function, $U$, defined by equation (36), to attain, at the median income nine sets of preselected values of elasticities of $U$. The parameter $A$ is normalized at 1.0.

Step 7: Solve for the price time series for $p_{3}$, from the first order conditions for total-expenditure constrained maximization of $U$, defined by equation (36).

Step 8: Compute $\mathrm{x}_{1}=\mathrm{y}_{1}+\mathrm{a}_{1}$ and $\mathrm{x}_{2}=\mathrm{y}_{2}+\mathrm{a}_{2}$ and $\mathrm{x}_{3}=\mathrm{Q}_{2}+\mathrm{a}_{3}$.

Step 9: Normalize the prices and quantities $\left(x_{1}, x_{2}, x_{3}\right)$ such that at the median income, they correspond to the point at which we obtained the true elasticities.

Step 10: Add disturbances to the quantities, $x_{1}, x_{2}$, and $x_{3}$, obtained from the previous steps. Those disturbance stochastic processes are normally distributed with mean zero and variance 1 . We increase the variability of the disturbances to capture the effects of increasing noise on the data.

Step 11: Compute total expenditure on $x_{1}, x_{2}$, and $x_{3}$.

Step 12: Estimate the models, and bootstrap those estimations 1,000 times, while adding the noise to the $x_{i}$ 's at each replication and recalculating total expenditure on $x_{1}, x_{2}$, and $x_{3}$. To avoid correlation between the disturbances that are added to the reference data sets, we generate a set of 10,000 random variables that are used as seeds in generating the normally distributed errors. The 1,000 estimates of the price and income elasticities and the elasticities of substitution are summarized by their means and standard errors, which are used to compare the estimated elasticities to the true elasticities. 


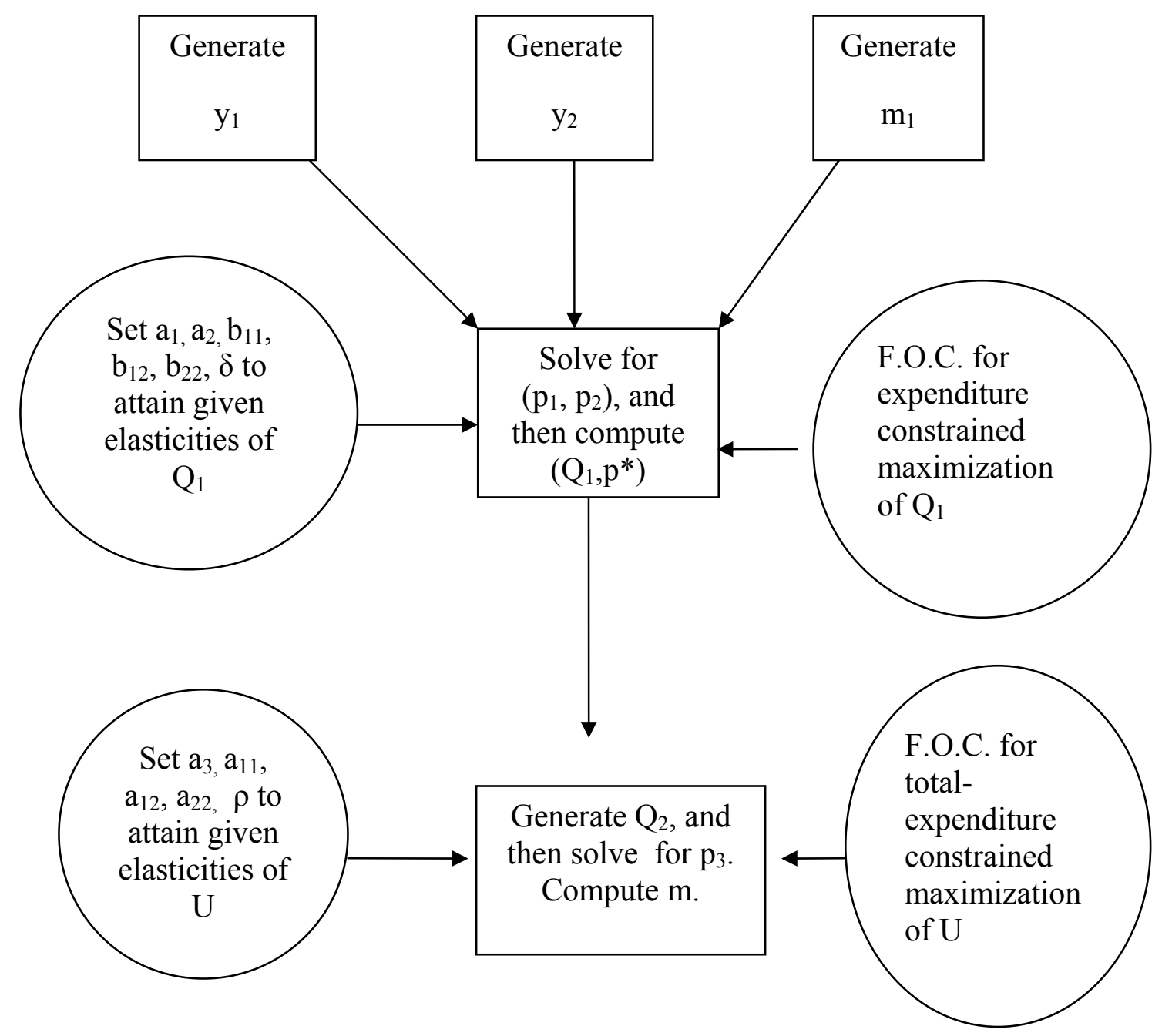

Figure 1: Data generation flow chart for each of the 9 cases

\section{Estimation methods}

We employ a version of iterated seemingly unrelated regression (SUR) to estimate the full nonlinear AIDS (PIGLOG) model. We check for robustness by also estimating by full information maximum likelihood (FIML). We use FIML to estimate the absolute price version of the Rotterdam model and the linearized AIDS model. 
In estimating the nonlinear AIDS model, we first pick starting values for the parameters of income's price deflator (9). We substitute those starting values into the income deflator and estimate the demand system (8), with the parameters of (9) treated as fixed. In the next step, the resulting parameters for (8) are substituted into (9), and the iteration process continues until convergence, defined to be when the differences between the parameter values in two successive estimation are all less than or equal to $10^{-2}$. This iterated SUR estimation procedure is analogous to the one conventionally used with the relative price version of the Rotterdam model, which has a similar source of nonlinearity from its use of the parameterized Frisch price index. As has been shown with the relative price version of the Rotterdam model, this iterated SUR estimator produces consistent estimates of all parameters and is considerably more convenient to use than FIML estimation, when the source of nonlinearity is a price aggregator function embedded within the model. $^{7}$

The Rotterdam model represented by equation (3) will be estimated with the following assumptions on the regressors and the disturbance vector. For each time $t, D Q_{t}$ and $D p_{1 t}, \ldots, D p_{n t}$ are nonstochastic. The disturbance vector, $\mathbf{v}_{t}=\left(v_{1 t}, \ldots, v_{n t}\right)^{\prime}$, has zero mean and time-independent contemporaneous covariance matrix, $\left[\omega_{i j}\right]$, which is a symmetric positive semi-definite $n \times n$ matrix with rank $n-1$ and satisfies $\sum_{j=1}^{n} \omega_{i j}=0$ for each $i$. Also $\mathrm{E}\left[\varepsilon_{i s} \varepsilon_{j t}\right]=0$ for $s \neq t$.

In addition, the theoretical symmetry of the Slutsky coefficient matrix $\left[\pi_{i j}\right]$ will be imposed along with the linear homogeneity restrictions, $\sum_{j=1}^{n} \pi_{i j}=0$ and $\sum_{i=1}^{n} \mu_{i}=1$.

\section{Performance of Different Price Approximations}

It is common in the literature to linearize the AIDS model by using Stone's nonparametric statistical index, (17), to approximate income's parameterized price-deflator. But that approximation has shortcomings. Pashardes (1993) has shown that errors resulting from that approximation can be seen as an omitted variable. The resulting estimates of the parameters of the demand functions may thereby be biased. In addition, Moschini(1995) pointed out that Stone's

\footnotetext{
${ }^{7}$ Although this estimator is consistent, it is not asymptotically efficient. Barnett's (1976) result on the asymptotic equivalence of FIML with iterated Aitken are not applicable here, since his proof assumes no overlap between the parameters on each side of the iteration. The purpose of this iterated SUR estimator with the relative price version of the Rotterdam model has been to capture the consistency acquired from joint estimation, while minimizing transmission of errors in estimation of the price aggregator function's parameters to the estimators of the demand function's parameters. We explore that potential contamination by also using FIML for comparison.
} 
index failed to satisfy the "commensurability" property, in the sense that the growth rate of the price index is not invariant to the unit of measurement of prices. Moschini suggests three alternative indexes: the Törnqvist index and two normalized forms of the Stone index. ${ }^{8}$ In this section, we will investigate whether these alternative price approximations perform better or worse than the exact price index, when preferences are generated from Barnett's (1977) WS-branch model.

\subsection{The Törnqvist price index}

Diewert (1976) showed that the Törnqvist index is exact for the translog unit cost function, ${ }^{9}$

$$
\log c_{0}(p)=\alpha_{0}+\sum_{k=1}^{N} \alpha_{k} \log p_{k}+\frac{1}{2} \sum_{k=1}^{N} \sum_{j=1}^{N} \gamma_{k j}^{*} \log p_{k} \log p_{j}
$$

where $\gamma_{i j}=\gamma_{j i}, \sum_{k=1}^{N} \alpha_{i}=1$, and $\sum_{k=1}^{N} \alpha_{k j}=0$ for $k=1,2, \ldots, N$. Therefore, the Törnqvist price index is a superlative price index, in the sense defined by Diewert (1976). The fixed-base Törnqvist price index (often called the Divisia price index in discrete time, when chained) is defined by:

$$
\log P_{t}^{T}=\frac{1}{2} \sum_{j}\left(w_{j t}+w_{j}^{0}\right) \log \frac{p_{j t}}{p_{j}^{0}} .
$$

Hence,

$$
\begin{aligned}
\frac{\partial \log P_{t}^{T}}{\partial \log p_{j t}} & =\frac{1}{2}\left[w_{j t}+\sum_{k=1}^{n} \log p_{k t} \frac{\partial w_{k t}}{\partial \log p_{j t}}\right]-\frac{1}{2} \sum_{k=1}^{n} \log p_{k}^{0}+\frac{1}{2} w_{j}^{0} \\
& =\frac{1}{2}\left[\left(w_{j t}+w_{j}^{0}\right)+\sum_{k=1}^{n} w_{k t} \log \left(\frac{p_{k t}}{p_{k}^{0}}\right) \frac{\partial \log w_{k t}}{\partial \log p_{j t}}\right]
\end{aligned}
$$

\footnotetext{
${ }^{8}$ We follow Moschini in using fixed base indexes, since chained indexes would diverge further from the underlying theory on which the AIDS model was derived. Nevertheless, we plan future research on the robustness of our conclusions to the use of chained indexes.

${ }^{9} \mathrm{~A}$ price index $\mathrm{P}$ is exact for a neoclassical aggregator function $f$ having unit cost function dual $c$, if $\mathrm{P}\left(\mathrm{p}_{1}, \mathrm{p}_{2}, \mathrm{~s}_{1}, \mathrm{~s}_{2}\right)=$ $\mathrm{c}\left(\mathrm{p}_{2}\right) / \mathrm{c}\left(\mathrm{p}_{1}\right)$, where $\left(\mathrm{x}^{1}, \mathrm{x}^{2}\right)$ is the solution to the maximization of the aggregator function $f$ subject to total cost constraint.
} 


$$
=\frac{1}{2}\left[\left(w_{j t}+w_{j}^{0}\right)+\sum_{k=1}^{n} w_{k t} \log \left(\frac{p_{k t}}{p_{k}^{0}}\right)\left(\varepsilon_{k j}+\delta_{k j}\right)\right],
$$

where $\varepsilon_{\mathrm{kj}}$ is the Marshallian cross price elasticity, (18), and $\delta_{\mathrm{kj}}$ is the Kronecker delta (14). Substituting (46) into (21), the uncompensated cross-price elasticity of demand for good $i$ with respect to the price of good $j$ is

$$
\varepsilon_{i j}=-\delta_{i j}+\frac{\gamma_{i j}}{w_{i}}-\left(\frac{1}{2}\right) \frac{\beta_{i}}{w_{i}}\left[\left(w_{j t}+w_{j}^{0}\right)+\sum_{k=1}^{n} w_{k t} \log \left(\frac{p_{k t}}{p_{k}^{0}}\right)\left(\varepsilon_{k j}+\delta_{k j}\right)\right] .
$$

Let $\mathbf{E}$ be the matrix of price elasticities. Equation (47) can be written in matrix notation as

$$
\mathbf{E}=\mathbf{A} *-\left[\frac{1}{2} \mathbf{k c} *^{\prime}(\mathbf{E}+\mathbf{I})\right]
$$

where $\mathbf{E}=\left[\varepsilon_{i j}\right]$ and $\mathbf{A}^{*}=\left[a_{i j}^{*}\right]$ are $n \times n$ matrices, with $\mathbf{E}$ the matrix of elasticities, and

$$
\begin{aligned}
& a_{i j}^{*}=-\delta_{i j}+\gamma_{i j} / w_{i}-\frac{\beta_{i}\left(w_{j t}+w_{j}^{0}\right)}{2 w_{i}}, \mathbf{c}^{*}=\left(c_{1}^{*}, c_{2}^{*}, \ldots, c_{n}^{*}\right)^{\prime} \text { with } c_{j}^{*}=w_{j} \log \left(\frac{p_{j t}}{p_{j}^{0}}\right), \text { and } \\
& \mathbf{K}=\left(k_{1}, k_{2}, \ldots, k_{n}\right)^{\prime} \text { with } k_{i}=\beta_{i} / w_{i} \text {. Solving (48) for } \mathbf{E} \text { yields }
\end{aligned}
$$

$$
\mathbf{E}=\left(\mathbf{I}+\frac{1}{2} \mathbf{k} \mathbf{c} *^{\prime}\right)^{-1}(\mathbf{A} *+\mathbf{I})-\mathbf{I} .
$$

The derivation of the income elasticities is analogous and uses

$$
\begin{aligned}
\frac{\partial \log P^{T}}{\partial \log m} & =\frac{1}{2} \sum_{k=1}^{n} \log \left(\frac{p_{k t}}{p_{k}^{0}}\right) \frac{\partial w_{k}}{\partial \log m} \\
& =\frac{1}{2} \sum_{k}^{n} w_{k t} \log \left(\frac{p_{k t}}{p_{k}^{0}}\right)\left(\eta_{k}-1\right) .
\end{aligned}
$$

Substituting (50) into the general expression for income elasticity as a function of the derivative of the log-change of the price index with respect to income, we obtain

$$
\eta_{i}=1+\frac{1}{w_{i}}\left[\beta_{i}-\frac{1}{2} \sum_{k}^{n} w_{k t} \log \left(\frac{p_{k t}}{p_{k}^{0}}\right)\left(\eta_{k}-1\right)\right]
$$

This expression can be written in matrix notation as follows: 


$$
\mathbf{n}=\mathbf{k}-\frac{1}{2} \mathbf{k} \mathbf{c}^{\prime} \mathbf{n}
$$

where $\mathbf{n}$ is as defined in (30). Hence $\mathbf{n}$ is an $\mathbf{n}$ dimensional vector with elements $n_{i}=\eta_{i}-1$. After some manipulation, the income elasticities are obtained. In matrix notation, after solving for $\mathbf{n}$, we get

$$
\mathbf{n}=\left(\mathbf{I}+\frac{1}{2} \mathbf{k} \mathbf{c} *^{\prime}\right)^{-1} \mathbf{k}
$$

\subsection{A first modified Stone's index (Paasche-like index )}

As shown by Moschini (1995), Stone's index can be modified to be invariant to the unit of measurement. We call the modified index the quasi-Paasche index, since it uses current period expenditure weights. The resulting price index in logarithms is

$$
\log P_{t}^{P}=\sum_{k} w_{k t} \log \frac{p_{k t}}{p_{k}^{0}} .
$$

Using this price index, the price elasticities will be slightly different from those generated using Stone's index. Indeed, equation (22) becomes, after some manipulations,

$$
\frac{\partial \log P_{t}^{P}}{\partial \log p_{j t}}=w_{j t}+\sum_{k} w_{k t} \log \frac{p_{k t}}{p_{k}^{0}} \frac{\partial \log w_{k t}}{\partial \log p_{j t}}
$$

Then the Marshallian price elasticities become analogous to (39), but with $\log p_{k}$ replaced by $\log p_{k t} / \log p_{k}^{0}$. We substitute (55) into (21) to acquire the price elasticities. In matrix notation, the matrix of price elasticities is given by

$$
\mathbf{E}=\left(\mathbf{I}+\mathbf{k c} *^{\prime}\right)^{-1}(\mathbf{A}+\mathbf{I})-\mathbf{I},
$$

where the variables are as defined in section 3.3.

We now compute the income derivatives of the price index:

$$
\begin{aligned}
\frac{\partial \log P_{t}^{P}}{\partial \log m_{t}} & =\sum_{k=1}^{n} \log \left(\frac{p_{k t}}{p_{k}^{0}}\right) \frac{\partial w_{k t}}{\partial \log m_{t}} \\
& =\sum_{k}^{n} w_{k t} \log \left(\frac{p_{k t}}{p_{k}^{0}}\right)\left(\eta_{k}-1\right) .
\end{aligned}
$$


In matrix notation, we have the following result, which is the analogous to (52):

$$
\mathbf{n}=\mathbf{k}-\mathbf{k} \mathbf{c} *^{\prime} \mathbf{n},
$$

where the variables are as previously defined. Solving for $\mathbf{n}$, we get

$$
\mathbf{n}=\left(\mathbf{I}+\mathbf{k} \mathbf{c}^{*^{\prime}}\right)^{-1} \mathbf{k}
$$

\subsection{A second modified Stone's index (Laspeyres-like index)}

Moschini (1995) also proposed a Laspeyres-like modification, $\mathrm{P}^{\mathrm{L}}$, of Stone's index. This modification is the analog to the Laspeyres index in logarithms, with weights computed from base period expenditures. The index is

$$
\log P_{t}^{L}=\sum_{j} w_{j}^{0} \log \frac{p_{j t}}{p_{j}^{0}} .
$$

Then it follows immediately that

$$
\frac{\partial \log P_{t}^{L}}{\partial \log p_{j t}}=w_{j}^{0} .
$$

The price elasticity of good $i$ with respect to the price of good $j$ is given by

$$
\varepsilon_{i j}=-\delta_{i j}+\frac{\gamma_{i j}}{w_{i t}}-\frac{\beta_{i}}{w_{i t}} w_{j}^{0} .
$$

The income elasticity of good $i$ becomes

$$
\eta_{i}=1+\frac{\beta_{i}}{w_{i t}},
$$

which is the same as (15) for the full nonlinear AIDS model. The formulas for the elasticities in this case are close to those of the full nonlinear AIDS, but not identical for the price elasticities.

\section{Estimation Results}

Tables 1-4 summarize the stochastic properties of the generated data. We report the mean and standard deviations of the quantities of three commodities, $x_{1}, x_{2}$ and $x_{3}$, of their respective prices, $p_{1}, p_{2}$ and $p_{3}$, and of the total-expenditure processes. Total expenditure appears more volatile than prices and quantities, as is consistent with real world data. We use four specifications 
of the total-expenditure processes, $\mathrm{m}_{2}, \mathrm{~m}_{3}, \mathrm{~m}_{4}$, and $\mathrm{m}_{5} .{ }^{10}$ See the footnote to table 1 for the definition of the four specifications. ${ }^{11}$ Tables $5-8$ provide comparisons of performance of the Rotterdam model with the full nonlinear AIDS (PIGLOG) model.

Looking at the estimates of income elasticities, we observe that the two models yield similar results. Quantitatively, when the AIDS overestimates or underestimates the income elasticities, the Rotterdam also does. Qualitatively though, the results are similar.

The two models depart from one another in their performance in recovering the true elasticities of substitution. In cases 1,2 , and 7 , where the true elasticity of substitution among goods in the inner aggregator function, $\sigma_{12}$, is high and low among pairs of goods in different aggregator functions, $\sigma_{13}$ and $\sigma_{23}$, both models produce higher estimates of $\sigma_{12}$, with the AIDS estimates lower than the Rotterdam estimates. The estimates of $\sigma_{13}$ from the Rotterdam are slightly closer to the true values and the ranking of the two models in estimating $\sigma_{23}$ favors the Rotterdam in two out of three cases. Qualitatively though, the Rotterdam dominates. In fact the AIDS misclassifies goods 1 and 3 as complements, when they are substitutes by construction. ${ }^{12}$

When all elasticities of substitution, $\sigma_{12}, \sigma_{13}, \sigma_{23}$, are moderately high (cases 3 and 5), both models perform relatively well in estimating all three of the elasticities of substitution. This finding that the Rotterdam model produces satisfactory estimates of elasticities of substitution in this case corroborates Barnett and Choi (1989), who acquired similarly positive results for the Rotterdam model with data produced from homothetic preferences.

The same observations apply when the elasticities of substitution are all low, as in case 6. Quantitatively, both models overestimate the elasticities, but the Rotterdam estimates of $\sigma_{13}$ and $\sigma_{23}$ are always slightly smaller than the AIDS estimates. When, as in case 4 , the elasticity within the aggregator function $\left(\sigma_{12}\right)$ is low and higher between goods in different aggregator functions, both models overestimate the lower elasticities $\left(\sigma_{12}, \sigma_{23}\right)$, and underestimate the higher elasticity of substitution.

\footnotetext{
${ }^{10}$ Recall that $\mathrm{m}_{1}$ has already been defined to be expenditure on only two of the three supernumerary quantities.

${ }^{11}$ In the specifications of the total expenditure processes, $\mathrm{m}_{2}, \mathrm{~m}_{3}, \mathrm{~m}_{4}$, and $\mathrm{m}_{5}$, the errors in total expenditure are a combination of the errors in the quantities.

${ }^{12}$ This tendency to classify two goods as complements, when they are actually substitutes, has been found previously for the translog model by Guilkey and Lovell (1980) and Guilkey, Lovell and Sickles (1983).
} 
But in cases 8 and 9 , all of the true elasticities of substitution are generally unusually high. In such cases, indifference curves are almost linear. In those cases, the two models performed poorly in estimating the higher elasticity of substitution between goods within the inner aggregator function, $\sigma_{12}$ (case 9). The precision of that estimated elasticity is very low, with the standard deviation being about three times greater than the estimated value of the elasticity. The AIDS accommodated the high elasticities better than the Rotterdam, since AIDS performed well in case 8 for the four specifications of the disturbances.

In case 9, that result on low precision was found with all of our specifications of the total expenditure process, as seen in tables 5 through 8 . Surprisingly, that low precision does not appear for the estimated substitutability between pairs of goods in different aggregator functions. For those pairs of good in cases 8 and 9, the two models yield positive, very high elasticities of substitution with small standard deviations. This high precision relative to that of the estimated elasticity between goods 1 and 2 is an unexpected finding.

A consistent pattern appears in the standard errors of the two models and in the regularity condition column of the tables. The AIDS produces smaller standard errors in all 9 cases and with all specifications of total-expenditure. The percentage of violations of the Slutsky matrix's negative semi-definiteness does not appear to be a factor in the relative performance of the two models. However, for high percentages of violations, the AIDS would perform qualitatively poorly (cases 1 , $5,9)$.

The theoretical properties of the demand function are known only when the regularity conditions are satisfied, since the duality theory on which the models' derivations are based require regularity. Hence the violations of negative semi-definiteness can be a source of the relatively poor performance of the AIDS model in estimating elasticities. ${ }^{13}$

The differences in the performances between the Rotterdam and the nonlinear AIDS models are not the result of the different estimation methods, namely the Iterated SUR (ITSUR) with the nonlinear AIDS model and FIML for the Rotterdam model and linearized AIDS model. For comparison, we also estimated the nonlinear AIDS with FIML. No significant differences were found between nonlinear AIDS with ITSUR and with FIML ${ }^{14}$.

\footnotetext{
${ }^{13}$ Regarding the nature of this problem with other models, see Caves and Christensen (1980), Barnett and Lee (1985), and Barnett et al. (1985).

${ }^{14}$ The results of that comparison can be obtained from the authors upon request.
} 
Tables 9a-9i contain the results of our estimations of the Linear Approximated AIDS (LAAIDS), when different price indices are used to produce the linearization. In the literature, the most popular LA-AIDS uses Stone's index, which produced the original AIDS model of Deaton and Muellbauer. We also estimated linear AIDS models using three other price indices: the Törnqvist index and the two price-normalized modified-Stone indexes, motivated by the Paasche and Laspeyres indexes. It is immediately evident that the linear approximations yield results very different from those obtained from the nonlinear AIDS model in tables 5-8.

The results from the four linearized models are very similar quantitatively and qualitatively. But the sign problems that the nonlinear AIDS models were displaying sometimes became worse. The results in tables 9a-9i show that the linearly approximated AIDS models perform significantly differently from the PIGLOG model they are designed to approximate.

\section{Conclusion}

Among the many demand specifications in the literature, the Rotterdam model and the Almost Ideal Demand System (AIDS) have particularly long histories, have been highly developed, and are often applied in consumer demand systems modeling. Using Monte Carlo techniques, we seek to determine which model performs better in terms of its ability to recover the true elasticities of demand. Three findings follow from this paper:

[1] Both the Rotterdam and the PIGLOG (fully nonlinear AIDS) models perform well, when substitution among goods is low. The higher the level of aggregation, the lower the elasticity of substitution among aggregates. Therefore when modeling consumer demand at the aggregate level, both models may yield correct estimates of the elasticities of substitution.

[2] When the elasticities of substitutions among goods is moderately high, both models perform well.

[3] When substitution among all goods is very high, the nonlinear PIGLOG perform better than the Rotterdam.

[4] The Rotterdam model appears better at recovering the true elasticities, when we implement exact aggregation within weakly separable branches of a utility tree. When attempting to build consistent aggregates, the Rotterdam appears to perform better. Within weakly separable branches of the utility tree, the nonlinear PIGLOG model may 
classify substitutes as complements or overestimate the elasticities of substitution among goods.

We derive the formulas for the linearized AIDS model's elasticities, when the Törnqvist price index or either of two modified Stone indexes are used to linearize the model. We find that these three indices, along with Stone's widely used price index, do not yield satisfactory results. The use of those linearizations exacerbates misclassification of goods as complements and leads to estimated elasticities different from those of the full nonlinear PIGLOG model, which the linearized AIDS models are designed to approximate.

These findings are robust in the sense that they do not change, whether we estimate the PIGLOG, AIDS, or Rotterdam models using ITSUR or FIML estimation. 


\section{References}

Allen RGD. 1938. Mathematical analysis for economists. Macmillan: London.

Allen RGD, Hicks JR. 1934. A reconsideration of the theory of value, II. Economica 1(2): 196-219.

Alston JM, Chalfant A. 1993. The silence of the Lamdas: a test for the Almost Ideal and Rotterdam models. American Journal of Agricultural Economics 75: 304-14.

Alston JM, Foster KA, Green R. 1994. Estimating elasticities with the linear approximate ideal demand system: some Monte Carlo results. Review of Economics and Statistics 76:351-56.

Arrow KJ, Chenery HB, Minhas BS, Solow RM. 1961. Capital-labor substitution and economic efficiency. Review of Economics and Statistics 43:225-50.

Banks J, Blundell R, Lewbel A. 1997. Quadratic Engel curves and consumer demand. Review of Economics and Statistics 79:527-39.

Barnett WA. 1976. Maximum likelihood and iterated Aitken estimation of non-linear systems of equations. Journal of the American Statistical Association 71:354-360.

Barnett WA. 1977. Recursive subaggregation and a generalized hypocycloidal demand model. Econometrica 45: 1117-1136.

Barnett WA. 1979. Theoretical foundations of the Rotterdam model. Review of Economic Studies 46: 109-30.

Barnett WA. 1983. New indices of money supply and the flexible Laurent demand system. Journal of Business and Economic Statistics 1: 7-23.

Barnett WA, Jonas A. 1983. The Muntz-Szatz demand system: an application of a globally well-behaved series expansion. Economic Letters 11(4): 337-42.

Barnett WA. 1985. The Minflex Laurent Translog flexible functional form. Journal of Econometrics 30: 33-44.

Barnett WA., Lee WY. 1985. The global properties of the Minflex Laurent, Generalized Leontief and Translog flexible functional forms. Econometrica 53: 1421-1437. 
Barnett WA, Lee WY, Wolfe MD. 1985. The three- dimensional global properties of the Minflex Laurent, Generalized Leontief, and Translog flexible functional forms. Journal of Econometrics 30: 3-31.

Barnett WA., Lee WY, Wolfe MD. 1987. The global properties of the two Minflex Laurent flexible functional forms. Journal of Econometrics 36: 281-98.

Barnett WA, Choi S. 1989. A Monte Carlo study of tests of blockwise weak separability. Journal of Business and Economic Statistics 7: 363-377.

Barnett WA, Yue P. 1998. Semiparametric estimation of the Asymptotically Ideal Model: the AIM demand system. In Nonparametric and Robust Inference, Advances in Econometrics 7, Rhodes G, Formby T(eds). JAI Press: Greenwich, CT; 229-52.

Barten AP. 1964. Consumer demand functions under conditions of almost additive preferences. Econometrica 32: $1-38$.

Barten AP. 1968. Estimating demand equations. Econometrica Vol. 36(2): 213-51.

Barten AP. 1977. The systems of consumer demand functions approach: A Review. Econometrica 45: 23-51.

Berndt ER, Darrough MN, Diewert WE. 1977. Flexible functional forms and expenditure distribution: an application to Canadian consumer demand functions. International Economic Review. 18: 651-75.

Blackorby C, Russell RR. 1981. The Morishima elasticity of substitution: symmetry, constancy, separability, and its relationship to the Hicks and Allen elasticities. Review of Economic Studies 48: 147-58.

Blackorby C, Russell RR. 1989. Will the real elasticity of substitution please stand up? (A comparison of the Allen/Uzawa and Morishima elasticities). American Economic Review 79: 882-888.

Caves DW, Christensen LR. 1980. Global properties of flexible functional forms. American Economic Review 70: 422-32.

Christensen LR, Jorgenson DW, Lau LJ. 1975. Transcendental logarithmic utility functions. American Economic Review 65: 367-83.

Cooper RJ, McLaren KR. 1996. A system of demand equations satisfying effectively global regularity conditions. Review of Economics and Statistics. 
Deaton A, Muellbauer J. 1980a. An Almost Ideal Demand System. American Economic Review 70: 312-26.

Deaton A, Muellbauer J. 1980b. Economics and consumer behavior. Cambridge University Press.

Denny M. 1974. The relationship between functional forms for production systems. Canadian Journal of Economics 7: 21-31.

Diewert WE. 1971. An Application of the Shephard duality theorem: a Generalized Leontief production function. Journal of Political Economy 79: 461-507.

Diewert WE. 1976. Essays in index number theory. North Holland: Amsterdam.

Fisher D, Fleissig AR, Serletis A. 2001. An empirical comparison of flexible demand system functional forms. Journal of Applied Econometrics 16: 59-80.

Gallant AR. 1981. On the bias in flexible functional forms and an essentially unbiased form: The Fourier flexible form. Journal of Econometrics 15: 211-45.

Green, R. and JM Alston. 1990. Elasticities in AIDS Models. American Journal of Agricultural Economics. 72: $442-445$.

Guilkey DK, Lovell CAK, Sickles RC. 1980. On the flexibility of the translog approximation. International Economic Review. 21:137-147.

Guilkey DK, Lovell CAK. 1983. A comparison of the performance of three flexible functional forms. International Economic Review. 24: 591-616.

Hicks JR. 1932. Theory of wages. Macmillan: London.

Kadiyala KR. 1972. Production functions and elasticity of substitution. Southern Economic Journal 38: 281-284.

Morishima M. 1967. A few suggestions on the theory of elasticity. Keizai Hyoron (Economic Review) 16: 149150.

Moschini G. 1995. Units of measurement and the Stone index in demand system estimation, American Journal of Agricultural Economics 77: 63-68. 
Pashardes A. 1993. Bias in the estimation of the Almost Ideal Demand System with the Stone index approximation. Economic Journal 103: 908-915.

Theil H. 1965. The information approach to demand analysis. Econometrica 33: 67-87.

Theil H. 1975a. Theory and measurement of consumer demand. Volume 1 . Amsterdam: North-Holland.

Theil H. 1975b. Theory and measurement of consumer demand. Volume 2. Amsterdam: North-Holland.

Uzawa H. 1962. Production functions with constant elasticity of substitution. Review of Economic Studies 30: 291-99. 


\section{Appendix A1:}

Selection of the values of the generating model's utility-function parameters and of the median vector of variables, (prices, quantities and expenditures).

In determining the values of the parameters of the utility function and the median data point at which we set the true elasticities, we followed the next 11 steps:

Step 1: Set the supernumerary quantities $y_{1}$ and $y_{2}$ and expenditures on $y_{1}$ and $y_{2}$ at the point of estimation.

Step 2: Select $b_{11}, b_{12}, b_{22}$, and $\delta$, the parameters of inner aggregator function $Q_{1}$, such that $b_{11}+b_{12}+b_{22}=1$ and $\delta<1 / 2$

Step 3: Compute R' using equation (41) and $\xi_{12}$, the elasticity of substitution between $y_{1}$ and $y_{2}$, from equation 40.

Step 4: Compute the marginal rate of substitution, $c$, set it equal to the price ratio, $p_{1} / p_{2}$, and solve for $p_{1}$ and $p_{2}$, where $c$ is defined by:

$$
c=\frac{\frac{\partial Q_{1}}{\partial y_{1}}}{\frac{\partial Q_{1}}{\partial y_{2}}} .
$$

Step 5: Compute the aggregate $Q_{1}$ and the dual price $p^{*}=\left(p_{1} \mathrm{y}_{1}+p_{2} \mathrm{y}_{2}\right) / \mathrm{Q}_{1}$.

Step 6: Set $y_{3}$ and select $a_{11}, a_{12}, a_{22}$, and $\rho$, such that $a_{11}+a_{12}+a_{22}=1$ and $\rho<1 / 2$. Then calculate the elasticity of substitution between $\mathrm{y}_{1}$ or $\mathrm{y}_{2}$ and $\mathrm{y}_{3}$ from equation 34 .

Step 7: Compute the marginal rate of substitution, $K C$, set it equal to the price ratio, $p^{*} / p_{3}$, solve for $p_{3}$, and compute $\widetilde{m}=p_{1} \mathrm{y}_{1}+p_{2} \mathrm{y}_{2}+p_{3} y_{3}$, where $K C$ is defined by:

$$
K C=\frac{\frac{\partial U}{\partial Q_{1}}}{\frac{\partial U}{\partial Q_{2}}} .
$$

Step 8: Set $a_{1} a_{2}$ and $a_{3}$ and compute $m$, the total expenditure on the $x$ 's.

Step 9: Compute (38) and (42), the elasticities of substitution among the three $x$ 's.

Step 10: Compute (39) and (43), the income and price elasticities.

Step 11: Vary the variables and parameters to create the nine cases. 
Table 1: Characteristics of the data sets, using the $\mathrm{m}_{2}$ total-expenditure process.

\begin{tabular}{|c|c|c|c|c|c|c|c|c|c|}
\hline Case & $\begin{array}{c}\text { Sample } \\
\text { size }\end{array}$ & Moment & $\mathrm{X}_{1}$ & $\mathrm{X}_{2}$ & $\mathrm{X}_{3}$ & $\mathrm{p}_{1}$ & $\mathrm{p}_{2}$ & $\mathrm{p}_{3}$ & $\mathrm{~m}_{2}$ \\
\hline \multirow[t]{2}{*}{1} & 61 & Mean & 12.50 & 17.47 & 12.93 & 5.87 & 5.07 & 3.31 & 204.19 \\
\hline & 61 & Std. dev. & 1.21 & 1.25 & 1.34 & 0.39 & 0.31 & 0.10 & 11.58 \\
\hline \multirow[t]{2}{*}{2} & 61 & Mean & 9.23 & 9.65 & 23.82 & 5.12 & 5.02 & 3.28 & 173.26 \\
\hline & 61 & Std. dev. & 1.26 & 1.23 & 1.96 & 0.40 & 0.34 & 0.14 & 9.55 \\
\hline \multirow[t]{2}{*}{3} & 61 & Mean & 8.83 & 7.56 & 34.73 & 5.37 & 7.06 & 7.98 & 376.83 \\
\hline & 61 & Std. dev. & 1.29 & 1.11 & 2.60 & 0.46 & 0.51 & 0.36 & 19.52 \\
\hline \multirow[t]{2}{*}{4} & 61 & Mean & 12.31 & 12.64 & 20.08 & 6.44 & 8.79 & 6.80 & 325.28 \\
\hline & 61 & Std. dev. & 1.56 & 1.36 & 1.90 & 0.55 & 0.64 & 0.31 & 17.28 \\
\hline \multirow[t]{2}{*}{5} & 61 & Mean & 9.79 & 12.25 & 16.01 & 1.95 & 8.14 & 12.79 & 322.16 \\
\hline & 61 & Std. dev. & 1.45 & 1.62 & 1.57 & 0.14 & 0.61 & 0.59 & 21.13 \\
\hline \multirow[t]{2}{*}{6} & 61 & Mean & 13.84 & 14.74 & 16.01 & 5.47 & 6.61 & 7.95 & 299.12 \\
\hline & 61 & Std. dev. & 1.59 & 1.44 & 1.51 & 0.47 & 0.48 & 0.34 & 15.42 \\
\hline \multirow[t]{2}{*}{7} & 61 & Mean & 8.28 & 7.85 & 23.10 & 1.14 & 11.14 & 8.27 & 286.82 \\
\hline & 61 & Std. dev. & 1.34 & 1.17 & 1.89 & 0.08 & 0.86 & 0.36 & 17.08 \\
\hline \multirow[t]{2}{*}{8} & 61 & Mean & 7.63 & 5.89 & 22.83 & 1.40 & 15.01 & 9.91 & 324.10 \\
\hline & 61 & Std. dev. & 1.33 & 1.21 & 1.93 & 0.10 & 1.16 & 0.56 & 24.37 \\
\hline \multirow[t]{2}{*}{9} & 61 & Mean & 7.41 & 5.82 & 16.62 & 1.49 & 15.12 & 16.50 & 371.92 \\
\hline & 61 & Std. dev. & 1.31 & 1.20 & 1.58 & 0.10 & 1.16 & 1.07 & 30.73 \\
\hline
\end{tabular}

The definition of each of the 9 cases, in terms of the elasticity settings, is provided and repeated in each of the tables below.

$\mathrm{m}_{2}=\mathrm{p}_{1}\left(\mathrm{x}_{1}+\tau_{1}\right)+\mathrm{p}_{2}\left(\mathrm{x}_{2}+\tau_{2}\right)+\mathrm{p}_{3}\left(\mathrm{x}_{3}+\tau_{3}\right)$

$\mathrm{m}_{3}=\mathrm{p}_{1}\left(\mathrm{x}_{1}+1.5 \tau_{1}\right)+\mathrm{p}_{2}\left(\mathrm{x}_{2}+1.5 \tau_{2}\right)+\mathrm{p}_{3}\left(\mathrm{x}_{3}+1.5 \tau_{3}\right)$

$\mathrm{m}_{4}=\mathrm{p}_{1}\left(\mathrm{x}_{1}+2 \tau_{1}\right)+\mathrm{p}_{2}\left(\mathrm{x}_{2}+2 \tau_{2}\right)+\mathrm{p}_{3}\left(\mathrm{x}_{3}+2 \tau_{3}\right)$

$\mathrm{m}_{5}=\mathrm{p}_{1}\left(\mathrm{x}_{1}+2.5 \tau_{1}\right)+\mathrm{p}_{2}\left(\mathrm{x}_{2}+2.5 \tau_{2}\right)+\mathrm{p}_{3}\left(\mathrm{x}_{3}+2.5 \tau_{3}\right)$

where the $\tau_{\mathrm{i}}(\mathrm{i}=1,2,3)$ are the disturbances used in producing the $\mathrm{x}_{1}, \mathrm{x}_{2}$, and $\mathrm{x}_{3}$ processes, respectively. They are independently normally distributed with mean zero and variance 1 . 
Table 2: Characteristics of the data sets, using the $\mathrm{m}_{3}$ total-expenditure process.

\begin{tabular}{|c|c|c|c|c|c|c|c|c|c|}
\hline Case & $\begin{array}{c}\text { Sample } \\
\text { size } \\
\end{array}$ & Moment & $\mathrm{X}_{1}$ & $\mathrm{X}_{2}$ & $\mathrm{X}_{3}$ & $\mathrm{p}_{1}$ & $\mathrm{p}_{2}$ & $\mathrm{p}_{3}$ & $\mathrm{~m}_{3}$ \\
\hline \multirow[t]{2}{*}{1} & 61 & Mean & 12.36 & 16.56 & 12.56 & 6.08 & 5.37 & 3.39 & 205.70 \\
\hline & 61 & Std. dev. & 2.05 & 1.76 & 1.75 & 0.47 & 0.37 & 0.15 & 14.22 \\
\hline \multirow[t]{2}{*}{2} & 61 & Mean & 9.28 & 9.72 & 23.80 & 5.12 & 5.02 & 3.28 & 173.88 \\
\hline & 61 & Std. dev. & 1.65 & 1.63 & 2.23 & 0.40 & 0.34 & 0.14 & 12.64 \\
\hline \multirow[t]{2}{*}{3} & 61 & Mean & 8.87 & 7.63 & 34.71 & 5.37 & 7.06 & 7.98 & 377.50 \\
\hline & 61 & Std. dev. & 1.70 & 1.54 & 2.77 & 0.46 & 0.51 & 0.36 & 23.15 \\
\hline \multirow[t]{2}{*}{4} & 61 & Mean & 12.36 & 12.72 & 20.05 & 6.44 & 8.79 & 6.80 & 326.01 \\
\hline & 61 & Std. dev. & 1.95 & 1.77 & 2.18 & 0.55 & 0.64 & 0.31 & 21.58 \\
\hline \multirow[t]{2}{*}{5} & 61 & Mean & 9.83 & 12.33 & 15.98 & 1.95 & 8.14 & 12.79 & 322.41 \\
\hline & 61 & Std. dev. & 1.87 & 2.04 & 1.90 & 0.14 & 0.61 & 0.59 & 26.48 \\
\hline \multirow[t]{2}{*}{6} & 61 & Mean & 13.88 & 14.81 & 15.98 & 5.47 & 6.61 & 7.95 & 299.69 \\
\hline & 61 & Std. dev. & 1.94 & 1.83 & 1.82 & 0.47 & 0.48 & 0.34 & 19.69 \\
\hline \multirow[t]{2}{*}{7} & 61 & Mean & 8.33 & 7.92 & 23.07 & 1.14 & 11.14 & 8.27 & 287.50 \\
\hline & 61 & Std. dev. & 1.77 & 1.60 & 2.16 & 0.08 & 0.86 & 0.36 & 22.79 \\
\hline \multirow[t]{2}{*}{8} & 61 & Mean & 7.68 & 5.96 & 22.80 & 1.40 & 15.01 & 9.91 & 324.86 \\
\hline & 61 & Std. dev. & 1.78 & 1.68 & 2.21 & 0.10 & 1.16 & 0.56 & 31.18 \\
\hline \multirow[t]{2}{*}{9} & 61 & Mean & 7.46 & 5.89 & 16.59 & 1.49 & 15.12 & 16.50 & 372.53 \\
\hline & 61 & Std. dev. & 1.77 & 1.67 & 1.91 & 0.10 & 1.16 & 1.07 & 38.48 \\
\hline
\end{tabular}

The definition of each of the 9 cases, in terms of the elasticity settings, is provided and repeated in each of the tables below.

$\mathrm{m}_{2}=\mathrm{p}_{1}\left(\mathrm{x}_{1}+\tau_{1}\right)+\mathrm{p}_{2}\left(\mathrm{x}_{2}+\tau_{2}\right)+\mathrm{p}_{3}\left(\mathrm{x}_{3}+\tau_{3}\right)$

$\mathrm{m}_{3}=\mathrm{p}_{1}\left(\mathrm{x}_{1}+1.5 \tau_{1}\right)+\mathrm{p}_{2}\left(\mathrm{x}_{2}+1.5 \tau_{2}\right)+\mathrm{p}_{3}\left(\mathrm{x}_{3}+1.5 \tau_{3}\right)$

$\mathrm{m}_{4}=\mathrm{p}_{1}\left(\mathrm{x}_{1}+2 \tau_{1}\right)+\mathrm{p}_{2}\left(\mathrm{x}_{2}+2 \tau_{2}\right)+\mathrm{p}_{3}\left(\mathrm{x}_{3}+2 \tau_{3}\right)$

$\mathrm{m}_{5}=\mathrm{p}_{1}\left(\mathrm{x}_{1}+2.5 \tau_{1}\right)+\mathrm{p}_{2}\left(\mathrm{x}_{2}+2.5 \tau_{2}\right)+\mathrm{p}_{3}\left(\mathrm{x}_{3}+2.5 \tau_{3}\right)$

where the $\tau_{\mathrm{i}}(\mathrm{i}=1,2,3)$ are the disturbances used in producing the $\mathrm{x}_{1}, \mathrm{x}_{2}$, and $\mathrm{x}_{3}$ processes, respectively. They are independently normally distributed with mean zero and variance 1 . 
Table 3: Characteristics of the data sets, using the $\mathrm{m}_{4}$ total-expenditure process.

\begin{tabular}{|c|c|c|c|c|c|c|c|c|c|}
\hline Case & $\begin{array}{c}\text { Sample } \\
\text { size }\end{array}$ & Moment & $\mathrm{X}_{1}$ & $\mathrm{X}_{2}$ & $\mathrm{x}_{3}$ & $\mathrm{p}_{1}$ & $\mathrm{p}_{2}$ & $\mathrm{p}_{3}$ & $\mathrm{~m}_{4}$ \\
\hline \multirow[t]{2}{*}{1} & 61 & Mean & 12.40 & 16.63 & 12.54 & 6.08 & 5.37 & 3.39 & 206.27 \\
\hline & 61 & Std. dev. & 2.52 & 2.16 & 2.15 & 0.47 & 0.37 & 0.15 & 18.17 \\
\hline \multirow[t]{2}{*}{2} & 61 & Mean & 9.32 & 9.79 & 23.77 & 5.12 & 5.02 & 3.28 & 174.49 \\
\hline & 61 & Std. dev. & 2.11 & 2.07 & 2.56 & 0.40 & 0.34 & 0.14 & 16.13 \\
\hline \multirow[t]{2}{*}{3} & 61 & Mean & 8.92 & 7.70 & 34.68 & 5.37 & 7.06 & 7.98 & 378.18 \\
\hline & 61 & Std. dev. & 2.17 & 2.01 & 3.01 & 0.46 & 0.51 & 0.36 & 27.58 \\
\hline \multirow[t]{2}{*}{4} & 61 & Mean & 12.40 & 12.79 & 20.03 & 6.44 & 8.79 & 6.80 & 326.75 \\
\hline & 61 & Std. dev. & 2.42 & 2.22 & 2.52 & 0.55 & 0.64 & 0.31 & 26.63 \\
\hline \multirow[t]{2}{*}{5} & 61 & Mean & 9.88 & 12.40 & 15.95 & 1.95 & 8.14 & 12.79 & 322.66 \\
\hline & 61 & Std. dev. & 2.34 & 2.50 & 2.27 & 0.14 & 0.61 & 0.59 & 32.59 \\
\hline \multirow[t]{2}{*}{6} & 61 & Mean & 13.93 & 14.88 & 15.95 & 5.47 & 6.61 & 7.95 & 300.26 \\
\hline & 61 & Std. dev. & 2.37 & 2.26 & 2.18 & 0.47 & 0.48 & 0.34 & 24.57 \\
\hline \multirow[t]{2}{*}{7} & 61 & Mean & 8.37 & 7.99 & 23.05 & 1.14 & 11.14 & 8.27 & 288.18 \\
\hline & 61 & Std. dev. & 2.26 & 2.06 & 2.49 & 0.08 & 0.86 & 0.36 & 29.05 \\
\hline \multirow[t]{2}{*}{8} & 61 & Mean & 7.72 & 6.03 & 22.78 & 1.40 & 15.01 & 9.91 & 325.62 \\
\hline & 61 & Std. dev. & 2.27 & 2.16 & 2.55 & 0.10 & 1.16 & 0.56 & 38.94 \\
\hline \multirow[t]{2}{*}{9} & 61 & Mean & 7.51 & 5.96 & 16.56 & 1.49 & 15.12 & 16.50 & 373.13 \\
\hline & 61 & Std. dev. & 2.27 & 2.15 & 2.29 & 0.10 & 1.16 & 1.07 & 47.49 \\
\hline
\end{tabular}

The definition of each of the 9 cases, in terms of the elasticity settings, is provided and repeated in each of the tables below.

$\mathrm{m}_{2}=\mathrm{p}_{1}\left(\mathrm{x}_{1}+\tau_{1}\right)+\mathrm{p}_{2}\left(\mathrm{x}_{2}+\tau_{2}\right)+\mathrm{p}_{3}\left(\mathrm{x}_{3}+\tau_{3}\right)$

$\mathrm{m}_{3}=\mathrm{p}_{1}\left(\mathrm{x}_{1}+1.5 \tau_{1}\right)+\mathrm{p}_{2}\left(\mathrm{x}_{2}+1.5 \tau_{2}\right)+\mathrm{p}_{3}\left(\mathrm{x}_{3}+1.5 \tau_{3}\right)$

$\mathrm{m}_{4}=\mathrm{p}_{1}\left(\mathrm{x}_{1}+2 \tau_{1}\right)+\mathrm{p}_{2}\left(\mathrm{x}_{2}+2 \tau_{2}\right)+\mathrm{p}_{3}\left(\mathrm{x}_{3}+2 \tau_{3}\right)$

$\mathrm{m}_{5}=\mathrm{p}_{1}\left(\mathrm{x}_{1}+2.5 \tau_{1}\right)+\mathrm{p}_{2}\left(\mathrm{x}_{2}+2.5 \tau_{2}\right)+\mathrm{p}_{3}\left(\mathrm{x}_{3}+2.5 \tau_{3}\right)$

where the $\tau_{\mathrm{i}}(\mathrm{i}=1,2,3)$ are the disturbances used in producing the $\mathrm{x}_{1}, \mathrm{x}_{2}$, and $\mathrm{x}_{3}$ processes, respectively. They are independently normally distributed with mean zero and variance 1 . 
Table 4: Characteristics of the data sets, using the $\mathrm{m}_{5}$ total-expenditure process.

\begin{tabular}{|c|c|c|c|c|c|c|c|c|c|}
\hline Case & $\begin{array}{c}\text { Sample } \\
\text { size }\end{array}$ & Moment & $\mathrm{X}_{1}$ & $\mathrm{X}_{2}$ & $\mathrm{X}_{3}$ & $p_{1}$ & $\mathrm{p}_{2}$ & $\mathrm{p}_{3}$ & $\mathrm{~m}_{5}$ \\
\hline \multirow[t]{2}{*}{1} & 61 & Mean & 12.45 & 16.70 & 12.51 & 6.08 & 5.37 & 3.39 & 206.84 \\
\hline & 61 & Std. dev. & 3.02 & 2.60 & 2.58 & 0.47 & 0.37 & 0.15 & 22.31 \\
\hline \multirow[t]{2}{*}{2} & 61 & Mean & 9.37 & 9.86 & 23.75 & 5.12 & 5.02 & 3.28 & 175.10 \\
\hline & 61 & Std. dev. & 2.61 & 2.54 & 2.93 & 0.40 & 0.34 & 0.14 & 19.80 \\
\hline \multirow[t]{2}{*}{3} & 61 & Mean & 8.96 & 7.77 & 34.66 & 5.37 & 7.06 & 7.98 & 378.85 \\
\hline & 61 & Std. dev. & 2.68 & 2.48 & 3.30 & 0.46 & 0.51 & 0.36 & 32.47 \\
\hline \multirow[t]{2}{*}{4} & 61 & Mean & 12.45 & 12.86 & 20.00 & 6.44 & 8.79 & 6.80 & 327.48 \\
\hline & 61 & Std. dev. & 2.91 & 2.68 & 2.90 & 0.55 & 0.64 & 0.31 & 32.06 \\
\hline \multirow[t]{2}{*}{5} & 61 & Mean & 9.92 & 12.47 & 15.93 & 1.95 & 8.14 & 12.79 & 322.91 \\
\hline & 61 & Std. dev. & 2.85 & 2.97 & 2.68 & 0.14 & 0.61 & 0.59 & 39.11 \\
\hline \multirow[t]{2}{*}{6} & 61 & Mean & 13.97 & 14.95 & 15.93 & 5.47 & 6.61 & 7.95 & 300.84 \\
\hline & 61 & Std. dev. & 2.85 & 2.71 & 2.59 & 0.47 & 0.48 & 0.34 & 29.74 \\
\hline \multirow[t]{2}{*}{7} & 61 & Mean & 8.42 & 8.06 & 23.02 & 1.14 & 11.14 & 8.27 & 288.86 \\
\hline & 61 & Std. dev. & 2.77 & 2.54 & 2.86 & 0.08 & 0.86 & 0.36 & 35.57 \\
\hline \multirow[t]{2}{*}{8} & 61 & Mean & 7.77 & 6.11 & 22.75 & 1.40 & 15.01 & 9.91 & 326.38 \\
\hline & 61 & Std. dev. & 2.80 & 2.65 & 2.93 & 0.10 & 1.16 & 0.56 & 47.19 \\
\hline \multirow[t]{2}{*}{9} & 61 & Mean & 7.55 & 6.04 & 16.54 & 1.49 & 15.12 & 16.50 & 373.73 \\
\hline & 61 & Std. dev. & 2.79 & 2.64 & 2.70 & 0.10 & 1.16 & 1.07 & 57.17 \\
\hline
\end{tabular}

The definition of each of the 9 cases, in terms of the elasticity settings, is provided and repeated in each of the tables below.

$\mathrm{m}_{2}=\mathrm{p}_{1}\left(\mathrm{x}_{1}+\tau_{1}\right)+\mathrm{p}_{2}\left(\mathrm{x}_{2}+\tau_{2}\right)+\mathrm{p}_{3}\left(\mathrm{x}_{3}+\tau_{3}\right)$

$\mathrm{m}_{3}=\mathrm{p}_{1}\left(\mathrm{x}_{1}+1.5 \tau_{1}\right)+\mathrm{p}_{2}\left(\mathrm{x}_{2}+1.5 \tau_{2}\right)+\mathrm{p}_{3}\left(\mathrm{x}_{3}+1.5 \tau_{3}\right)$

$\mathrm{m}_{4}=\mathrm{p}_{1}\left(\mathrm{x}_{1}+2 \tau_{1}\right)+\mathrm{p}_{2}\left(\mathrm{x}_{2}+2 \tau_{2}\right)+\mathrm{p}_{3}\left(\mathrm{x}_{3}+2 \tau_{3}\right)$

$\mathrm{m}_{5}=\mathrm{p}_{1}\left(\mathrm{x}_{1}+2.5 \tau_{1}\right)+\mathrm{p}_{2}\left(\mathrm{x}_{2}+2.5 \tau_{2}\right)+\mathrm{p}_{3}\left(\mathrm{x}_{3}+2.5 \tau_{3}\right)$

where the $\tau_{\mathrm{i}}(\mathrm{i}=1,2,3)$ are the disturbances used in producing the $\mathrm{x}_{1}, \mathrm{x}_{2}$, and $\mathrm{x}_{3}$ processes, respectively. They are independently normally distributed with mean zero and variance 1 . 
Table 5: True and estimated elasticities using the $\mathrm{m}_{2}$ total-expenditure process

\begin{tabular}{|c|c|c|c|c|c|c|c|c|c|c|c|c|c|}
\hline \multirow{3}{*}{ Models } & \multicolumn{6}{|c|}{$\begin{array}{l}\text { Elasticities of substitution } \\
\end{array}$} & \multicolumn{6}{|c|}{$\begin{array}{c}\text { Income elasticities } \\
\end{array}$} & \multirow{3}{*}{$\begin{array}{c}\text { Regulation } \\
\text { condition }\end{array}$} \\
\hline & \multicolumn{3}{|c|}{ True values } & \multicolumn{3}{|c|}{ Estimated values } & \multicolumn{3}{|c|}{ True values } & \multicolumn{3}{|c|}{ Estimated values } & \\
\hline & $\sigma_{12}$ & $\sigma_{13}$ & $\sigma_{23}$ & $\tilde{\sigma}_{12}$ & $\tilde{\sigma}_{13}$ & $\tilde{\sigma}_{23}$ & $\eta_{1}$ & $\eta_{2}$ & $\eta_{3}$ & $\tilde{\eta}_{1}$ & $\tilde{\eta}_{2}$ & $\tilde{\eta}_{3}$ & \\
\hline $\begin{array}{l}\text { Case 1: } \\
\quad \text { Rotterdam }\end{array}$ & \multirow[b]{2}{*}{1.22} & \multirow[b]{2}{*}{.85} & \multirow[b]{2}{*}{.85} & $\begin{array}{c}2.31 \\
(0.02)\end{array}$ & $\begin{array}{c}0.74 \\
(0.04)\end{array}$ & $\begin{array}{c}.97 \\
(0.03) \\
\end{array}$ & \multirow[b]{2}{*}{.87} & \multirow[b]{2}{*}{.88} & \multirow[b]{2}{*}{1.46} & $\begin{array}{c}1.30 \\
(0.01)\end{array}$ & $\begin{array}{c}0.86 \\
(0.01)\end{array}$ & $\begin{array}{c}0.77 \\
(0.01)\end{array}$ & 0.90 \\
\hline AIDS & & & & $\begin{array}{l}2.25 \\
(.02) \\
\end{array}$ & $\begin{array}{c}.99 \\
(.01) \\
\end{array}$ & $\begin{array}{l}1.00 \\
(.01) \\
\end{array}$ & & & & $\begin{array}{l}1.21 \\
(.00)\end{array}$ & $\begin{array}{l}.86 \\
(.00)\end{array}$ & $\begin{array}{c}.91 \\
(.01)\end{array}$ & 0.29 \\
\hline $\begin{array}{l}\text { Case 2: } \\
\quad \text { Rotterdam }\end{array}$ & \multirow[b]{2}{*}{2.98} & \multirow[b]{2}{*}{.67} & \multirow[b]{2}{*}{.68} & $\begin{array}{c}3.63 \\
(0.05)\end{array}$ & $\begin{array}{c}0.38 \\
(0.03)\end{array}$ & $\begin{array}{c}1.12 \\
(0.02)\end{array}$ & \multirow[b]{2}{*}{1.25} & \multirow[b]{2}{*}{1.27} & \multirow[b]{2}{*}{.68} & $\begin{array}{c}1.66 \\
(0.01)\end{array}$ & $\begin{array}{c}1.29 \\
(0.01)\end{array}$ & $\begin{array}{c}0.44 \\
(0.00)\end{array}$ & 0.93 \\
\hline AIDS & & & & $\begin{array}{l}3.12 \\
(.03)\end{array}$ & $\begin{array}{l}.21 \\
(.02)\end{array}$ & $\begin{array}{l}1.46 \\
(.01)\end{array}$ & & & & $\begin{array}{l}1.49 \\
(.01)\end{array}$ & $\begin{array}{l}1.19 \\
(.01)\end{array}$ & $\begin{array}{c}.60 \\
(.00)\end{array}$ & 0.96 \\
\hline $\begin{array}{l}\text { Case 3: } \\
\text { Rotterdam } \\
\end{array}$ & \multirow[b]{2}{*}{1.82} & \multirow[b]{2}{*}{1.29} & \multirow[b]{2}{*}{1.27} & $\begin{array}{c}2.37 \\
(0.14) \\
\end{array}$ & $\begin{array}{c}1.05 \\
(0.04) \\
\end{array}$ & $\begin{array}{c}1.80 \\
(0.05) \\
\end{array}$ & \multirow[b]{2}{*}{1.33} & \multirow[b]{2}{*}{1.30} & \multirow[b]{2}{*}{.89} & $\begin{array}{c}1.39 \\
(0.01) \\
\end{array}$ & $\begin{array}{c}2.53 \\
(0.02)\end{array}$ & $\begin{array}{c}0.67 \\
(0.00) \\
\end{array}$ & 0.80 \\
\hline AIDS & & & & $\begin{array}{l}1.47 \\
(.06) \\
\end{array}$ & $\begin{array}{l}1.24 \\
(.02) \\
\end{array}$ & $\begin{array}{l}2.28 \\
(.02) \\
\end{array}$ & & & & $\begin{array}{l}1.26 \\
(.01) \\
\end{array}$ & $\begin{array}{l}2.01 \\
(.01) \\
\end{array}$ & $\begin{array}{l}.78 \\
(.00) \\
\end{array}$ & 0.81 \\
\hline $\begin{array}{l}\text { Case 4: } \\
\quad \text { Rotterdam }\end{array}$ & \multirow[b]{2}{*}{.52} & \multirow[b]{2}{*}{1.20} & \multirow[b]{2}{*}{.91} & $\begin{array}{c}1.40 \\
(0.03)\end{array}$ & $\begin{array}{c}.87 \\
(0.04)\end{array}$ & $\begin{array}{c}1.14 \\
(0.03)\end{array}$ & \multirow[b]{2}{*}{.82} & \multirow[b]{2}{*}{.62} & \multirow[b]{2}{*}{1.40} & $\begin{array}{c}.96 \\
(0.01) \\
\end{array}$ & $\begin{array}{c}1.29 \\
(0.01)\end{array}$ & $\begin{array}{c}0.79 \\
(0.00)\end{array}$ & 0.81 \\
\hline AIDS & & & & $\begin{array}{l}1.16 \\
(.01)\end{array}$ & $\begin{array}{l}1.13 \\
(.02)\end{array}$ & $\begin{array}{l}1.58 \\
(.01)\end{array}$ & & & & $\begin{array}{l}.94 \\
(.01)\end{array}$ & $\begin{array}{l}1.17 \\
(.00)\end{array}$ & $\begin{array}{c}.89 \\
(.00)\end{array}$ & 0.95 \\
\hline $\begin{array}{l}\text { Case 5: } \\
\quad \text { Rotterdam }\end{array}$ & & & & $\begin{array}{c}2.10 \\
(0.13) \\
\end{array}$ & $\begin{array}{c}2.72 \\
(0.08) \\
\end{array}$ & $\begin{array}{c}1.79 \\
(0.04) \\
\end{array}$ & & & & $\begin{array}{c}.41 \\
(0.01) \\
\end{array}$ & $\begin{array}{c}.93 \\
(0.01) \\
\end{array}$ & $\begin{array}{c}1.09 \\
(0.00) \\
\end{array}$ & 0.87 \\
\hline AIDS & 1.90 & 1.33 & 1.28 & $\begin{array}{l}4.38 \\
(.03)\end{array}$ & $\begin{array}{l}1.66 \\
(.03)\end{array}$ & $\begin{array}{l}1.49 \\
(.01)\end{array}$ & 1.04 & 1.00 & 1.00 & $\begin{array}{c}.50 \\
(.01)\end{array}$ & $\begin{array}{c}.95 \\
(.01)\end{array}$ & $\begin{array}{l}1.07 \\
(.00)\end{array}$ & 0.01 \\
\hline $\begin{array}{l}\text { Case } 6: \\
\text { Rotterdam }\end{array}$ & & & & $\begin{array}{c}1.33 \\
(0.02) \\
\end{array}$ & $\begin{array}{c}.97 \\
(0.03) \\
\end{array}$ & $\begin{array}{c}.97 \\
(0.02) \\
\end{array}$ & & & & $\begin{array}{c}1.01 \\
(0.01)\end{array}$ & $\begin{array}{c}0.88 \\
(0.01)\end{array}$ & $\begin{array}{c}1.09 \\
(0.01)\end{array}$ & 0.91 \\
\hline AIDS & 67 & .76 & .68 & $\begin{array}{l}1.27 \\
(.01)\end{array}$ & $\begin{array}{l}1.00 \\
(.02)\end{array}$ & $\begin{array}{l}.99 \\
(.01)\end{array}$ & .89 & .80 & 1.21 & $\begin{array}{c}.99 \\
(.01)\end{array}$ & $\begin{array}{c}.88 \\
(.00)\end{array}$ & $\begin{array}{l}1.10 \\
(.00)\end{array}$ & 0.55 \\
\hline $\begin{array}{l}\text { Case } 7: \\
\quad \text { Rotterdam }\end{array}$ & & & & $\begin{array}{c}5.43 \\
(0.07)\end{array}$ & $\begin{array}{c}0.97 \\
(0.03)\end{array}$ & $\begin{array}{c}1.04 \\
(0.01)\end{array}$ & & & & $\begin{array}{c}0.38 \\
(0.01)\end{array}$ & $\begin{array}{c}1.93 \\
(0.01)\end{array}$ & $\begin{array}{c}.60 \\
(0.00)\end{array}$ & 0.99 \\
\hline AIDS & 3.20 & .76 & .76 & $\begin{array}{l}5.35 \\
(.05) \\
\end{array}$ & $\begin{array}{l}1.03 \\
(.02) \\
\end{array}$ & $\begin{array}{l}.99 \\
(.01) \\
\end{array}$ & 1.44 & 1.44 & .78 & $\begin{array}{l}.54 \\
(.01) \\
\end{array}$ & $\begin{array}{l}1.73 \\
(.01) \\
\end{array}$ & $\begin{array}{c}.69 \\
(.00) \\
\end{array}$ & 0.88 \\
\hline $\begin{array}{l}\text { Case 8: } \\
\quad \text { Rotterdam }\end{array}$ & & & & $\begin{array}{c}-.59 \\
(0.05)\end{array}$ & $\begin{array}{c}3.61 \\
(0.15)\end{array}$ & $\begin{array}{c}1.63 \\
(0.09)\end{array}$ & & & & $\begin{array}{c}0.30 \\
(0.01)\end{array}$ & $\begin{array}{l}2.38 \\
(0.01\end{array}$ & $\begin{array}{c}0.51 \\
(0.00)\end{array}$ & 0.62 \\
\hline AIDS & 3.22 & 2.22 & 2.17 & $\begin{array}{l}3.06 \\
(.07) \\
\end{array}$ & $\begin{array}{l}2.40 \\
(.05) \\
\end{array}$ & $\begin{array}{l}3.53 \\
(.02) \\
\end{array}$ & 1.45 & 1.41 & .82 & $\begin{array}{l}.40 \\
(.01) \\
\end{array}$ & $\begin{array}{l}2.16 \\
(.01) \\
\end{array}$ & $\begin{array}{l}.58 \\
(.00) \\
\end{array}$ & 0.39 \\
\hline $\begin{array}{l}\text { Case 9: } \\
\text { Rotterdam }\end{array}$ & & & & $\begin{array}{l}-9.42 \\
(0.76)\end{array}$ & $\begin{array}{c}7.64 \\
(0.27)\end{array}$ & $\begin{array}{c}4.60 \\
(0.23)\end{array}$ & & & & $\begin{array}{c}0.27 \\
(0.01)\end{array}$ & $\begin{array}{c}1.84 \\
(0.01)\end{array}$ & $\begin{array}{c}0.77 \\
(0.00)\end{array}$ & 0.64 \\
\hline AIDS & 4.13 & 4.65 & 4.54 & $\begin{array}{l}-.64 \\
(.16)\end{array}$ & $\begin{array}{l}4.88 \\
(.08) \\
\end{array}$ & $\begin{array}{l}6.43 \\
(.04)\end{array}$ & 1.45 & 1.41 & .82 & $\begin{array}{l}.38 \\
(.01) \\
\end{array}$ & $\begin{array}{l}1.70 \\
(.01)\end{array}$ & $\begin{array}{c}.81 \\
(.00)\end{array}$ & 0.01 \\
\hline
\end{tabular}

Note: The regularity condition is the percent of non-violations of negative semi-definiteness of the Slutsky matrix. Numbers in parentheses are standard errors. AIDS is the fully nonlinear PIGLOG model estimated by iterated SUR. 
Table 6: True and estimated elasticities using the $m_{3}$ total-expenditure process

\begin{tabular}{|c|c|c|c|c|c|c|c|c|c|c|c|c|c|}
\hline \multirow{3}{*}{ Models } & \multicolumn{6}{|c|}{$\begin{array}{c}\text { Elasticities of substitution } \\
\end{array}$} & \multicolumn{6}{|c|}{ Income elasticities } & \multirow{3}{*}{$\begin{array}{c}\text { Regulation } \\
\text { condition }\end{array}$} \\
\hline & \multicolumn{3}{|c|}{ True values } & \multicolumn{3}{|c|}{ Estimated values } & \multicolumn{3}{|c|}{ True values } & \multicolumn{3}{|c|}{ Estimated values } & \\
\hline & $\sigma_{12}$ & $\sigma_{13}$ & $\sigma_{23}$ & $\tilde{\sigma}_{12}$ & $\tilde{\sigma}_{13}$ & $\tilde{\sigma}_{23}$ & $\eta_{1}$ & $\eta_{2}$ & $\eta_{3}$ & $\tilde{\eta}_{1}$ & $\tilde{\eta}_{2}$ & $\tilde{\eta}_{3}$ & \\
\hline $\begin{array}{l}\text { Case 1: } \\
\text { Rotterdam }\end{array}$ & \multirow[b]{2}{*}{1.22} & \multirow[b]{2}{*}{.85} & \multirow[b]{2}{*}{.85} & $\begin{array}{c}2.25 \\
(0.03) \\
\end{array}$ & $\begin{array}{c}0.44 \\
(0.06) \\
\end{array}$ & $\begin{array}{c}1.16 \\
(0.04) \\
\end{array}$ & \multirow[b]{2}{*}{.87} & \multirow[b]{2}{*}{.88} & \multirow[b]{2}{*}{1.46} & $\begin{array}{c}1.36 \\
(0.01) \\
\end{array}$ & $\begin{array}{c}0.82 \\
(0.01) \\
\end{array}$ & $\begin{array}{c}0.77 \\
(0.01) \\
\end{array}$ & 0.73 \\
\hline AIDS & & & & $\begin{array}{l}1.90 \\
(.02) \\
\end{array}$ & $\begin{array}{c}.32 \\
(.03) \\
\end{array}$ & $\begin{array}{l}1.40 \\
(.02) \\
\end{array}$ & & & & $\begin{array}{l}1.31 \\
(.01) \\
\end{array}$ & $\begin{array}{c}.81 \\
(.00) \\
\end{array}$ & $\begin{array}{c}.83 \\
(.01) \\
\end{array}$ & 0.23 \\
\hline $\begin{array}{l}\text { Case 2: } \\
\quad \text { Rotterdam }\end{array}$ & \multirow[b]{2}{*}{2.98} & \multirow[b]{2}{*}{.67} & \multirow[b]{2}{*}{.68} & $\begin{array}{c}3.67 \\
(0.07)\end{array}$ & $\begin{array}{c}0.33 \\
(0.04)\end{array}$ & $\begin{array}{c}1.13 \\
(0.03)\end{array}$ & \multirow[b]{2}{*}{1.25} & \multirow[b]{2}{*}{1.27} & \multirow[b]{2}{*}{.68} & $\begin{array}{c}1.72 \\
(0.01)\end{array}$ & $\begin{array}{c}1.31 \\
(0.01)\end{array}$ & $\begin{array}{c}0.39 \\
(0.00)\end{array}$ & 0.78 \\
\hline AIDS & & & & $\begin{array}{l}3.08 \\
(.05) \\
\end{array}$ & $\begin{array}{l}-.16 \\
(.03) \\
\end{array}$ & $\begin{array}{l}1.58 \\
(.02) \\
\end{array}$ & & & & $\begin{array}{l}1.62 \\
(.01) \\
\end{array}$ & $\begin{array}{l}1.25 \\
(.01) \\
\end{array}$ & $\begin{array}{c}.49 \\
(.00) \\
\end{array}$ & 0.80 \\
\hline $\begin{array}{l}\text { Case 3: } \\
\text { Rotterdam } \\
\end{array}$ & \multirow[b]{2}{*}{1.82} & \multirow[b]{2}{*}{1.29} & \multirow[b]{2}{*}{1.27} & $\begin{array}{c}2.63 \\
(0.21) \\
\end{array}$ & $\begin{array}{c}.96 \\
(0.06) \\
\end{array}$ & $\begin{array}{c}1.86 \\
(0.07) \\
\end{array}$ & \multirow[b]{2}{*}{1.33} & \multirow[b]{2}{*}{1.30} & \multirow[b]{2}{*}{.89} & $\begin{array}{c}1.44 \\
(0.01) \\
\end{array}$ & $\begin{array}{c}2.83 \\
(0.02) \\
\end{array}$ & $\begin{array}{c}0.60 \\
(0.00) \\
\end{array}$ & 0.64 \\
\hline AIDS & & & & $\begin{array}{l}1.46 \\
(.09) \\
\end{array}$ & $\begin{array}{l}1.13 \\
(.03) \\
\end{array}$ & $\begin{array}{l}2.64 \\
(.02) \\
\end{array}$ & & & & $\begin{array}{l}1.35 \\
(.01)\end{array}$ & $\begin{array}{l}2.40 \\
(.01)\end{array}$ & $\begin{array}{c}.69 \\
(.00)\end{array}$ & 0.86 \\
\hline $\begin{array}{l}\text { Case 4: } \\
\text { Rotterdam }\end{array}$ & \multirow[b]{2}{*}{.52} & \multirow[b]{2}{*}{1.20} & \multirow[b]{2}{*}{.91} & $\begin{array}{c}1.49 \\
(0.05)\end{array}$ & $\begin{array}{c}.75 \\
(0.06)\end{array}$ & $\begin{array}{c}1.09 \\
(0.05)\end{array}$ & \multirow[b]{2}{*}{.82} & \multirow[b]{2}{*}{.62} & \multirow[b]{2}{*}{1.40} & $\begin{array}{c}.96 \\
(0.01)\end{array}$ & $\begin{array}{c}1.38 \\
(0.01)\end{array}$ & $\begin{array}{c}0.73 \\
(0.01)\end{array}$ & 0.67 \\
\hline AIDS & & & & $\begin{array}{l}1.22 \\
(.02)\end{array}$ & $\begin{array}{l}1.02 \\
(.03)\end{array}$ & $\begin{array}{l}1.68 \\
(.01)\end{array}$ & & & & $\begin{array}{l}.95 \\
(.01)\end{array}$ & $\begin{array}{l}1.29 \\
(.01)\end{array}$ & $\begin{array}{c}.80 \\
(.00)\end{array}$ & 0.97 \\
\hline $\begin{array}{l}\text { Case 5: } \\
\quad \text { Rotterdam }\end{array}$ & & & & $\begin{array}{c}1.93 \\
(0.19)\end{array}$ & $\begin{array}{c}2.90 \\
(0.12)\end{array}$ & $\begin{array}{c}1.81 \\
(0.07)\end{array}$ & & & & $\begin{array}{c}.34 \\
(0.01)\end{array}$ & $\begin{array}{c}.94 \\
(0.01)\end{array}$ & $\begin{array}{c}1.09 \\
(0.00)\end{array}$ & 0.70 \\
\hline AIDS & 1.90 & 1.33 & 1.28 & $\begin{array}{l}4.63 \\
(.05) \\
\end{array}$ & $\begin{array}{l}1.67 \\
(.04) \\
\end{array}$ & $\begin{array}{l}1.49 \\
(.01) \\
\end{array}$ & 1.04 & 1.00 & 1.00 & $\begin{array}{l}.37 \\
(.01) \\
\end{array}$ & $\begin{array}{c}.95 \\
(.01) \\
\end{array}$ & $\begin{array}{l}1.08 \\
(.00) \\
\end{array}$ & 0.05 \\
\hline $\begin{array}{l}\text { Case } 6: \\
\text { Rotterdam } \\
\end{array}$ & & & & $\begin{array}{c}1.33 \\
(0.04) \\
\end{array}$ & $\begin{array}{c}.96 \\
(0.04) \\
\end{array}$ & $\begin{array}{c}.98 \\
(0.03) \\
\end{array}$ & & & & $\begin{array}{c}1.01 \\
(0.01) \\
\end{array}$ & $\begin{array}{c}0.88 \\
(0.01) \\
\end{array}$ & $\begin{array}{c}1.08 \\
(0.01) \\
\end{array}$ & 0.77 \\
\hline AIDS & .67 & .76 & .68 & $\begin{array}{l}1.27 \\
(.02)\end{array}$ & $\begin{array}{l}1.00 \\
(.02)\end{array}$ & $\begin{array}{l}1.00 \\
(.01)\end{array}$ & .89 & .80 & 1.21 & $\begin{array}{l}1.00 \\
(.01)\end{array}$ & $\begin{array}{c}.88 \\
(.00)\end{array}$ & $\begin{array}{l}1.09 \\
(.00)\end{array}$ & 0.58 \\
\hline $\begin{array}{l}\text { Case 7: } \\
\quad \text { Rotterdam } \\
\end{array}$ & & & & $\begin{array}{c}5.50 \\
(0.11) \\
\end{array}$ & $\begin{array}{c}0.97 \\
(0.05) \\
\end{array}$ & $\begin{array}{c}1.05 \\
(0.02) \\
\end{array}$ & & & & $\begin{array}{c}0.31 \\
(0.01) \\
\end{array}$ & $\begin{array}{c}2.02 \\
(0.01) \\
\end{array}$ & $\begin{array}{c}.57 \\
(0.00) \\
\end{array}$ & 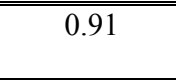 \\
\hline AIDS & 3.20 & .76 & .76 & $\begin{array}{l}5.30 \\
(.07)\end{array}$ & $\begin{array}{l}1.13 \\
(.03)\end{array}$ & $\begin{array}{l}.88 \\
(.01)\end{array}$ & 1.44 & 1.44 & .78 & $\begin{array}{c}.41 \\
(.01)\end{array}$ & $\begin{array}{l}1.90 \\
(.01)\end{array}$ & $\begin{array}{c}.62 \\
(.00)\end{array}$ & 0.89 \\
\hline $\begin{array}{l}\text { Case 8: } \\
\quad \text { Rotterdam }\end{array}$ & & & & $\begin{array}{c}-.94 \\
(0.50)\end{array}$ & $\begin{array}{c}3.79 \\
(0.23)\end{array}$ & $\begin{array}{c}1.53 \\
(0.14)\end{array}$ & & & & $\begin{array}{c}0.22 \\
(0.01)\end{array}$ & $\begin{array}{l}2.52 \\
(0.01\end{array}$ & $\begin{array}{c}0.46 \\
(0.00)\end{array}$ & 0.50 \\
\hline AIDS & 3.22 & 2.22 & 2.17 & $\begin{array}{l}3.29 \\
(.10)\end{array}$ & $\begin{array}{l}2.39 \\
(.07)\end{array}$ & $\begin{array}{l}3.67 \\
(.03)\end{array}$ & 1.45 & 1.41 & .82 & $\begin{array}{l}.27 \\
(.01)\end{array}$ & $\begin{array}{l}2.39 \\
(.01) \\
\end{array}$ & $\begin{array}{l}.50 \\
(.00)\end{array}$ & 0.63 \\
\hline $\begin{array}{l}\text { Case 9: } \\
\text { Rotterdam }\end{array}$ & & & & $\begin{array}{l}-10.03 \\
(0.76)\end{array}$ & $\begin{array}{l}7.94 \\
(0.27)\end{array}$ & $\begin{array}{c}4.54 \\
(0.23)\end{array}$ & & & & $\begin{array}{c}0.19 \\
(0.01)\end{array}$ & $\begin{array}{c}1.94 \\
(0.01)\end{array}$ & $\begin{array}{c}0.74 \\
(0.00)\end{array}$ & 0.51 \\
\hline AIDS & 4.13 & 4.65 & 4.54 & $\begin{array}{l}-.07 \\
(.24) \\
\end{array}$ & $\begin{array}{l}4.82 \\
(.12) \\
\end{array}$ & $\begin{array}{l}6.67 \\
(.06) \\
\end{array}$ & 1.45 & 1.41 & .82 & $\begin{array}{c}.24 \\
(.01) \\
\end{array}$ & $\begin{array}{l}1.84 \\
(.01) \\
\end{array}$ & $\begin{array}{c}.77 \\
(.00) \\
\end{array}$ & 0.03 \\
\hline
\end{tabular}

Note: The regularity condition is the percent of non-violations of negative semi-definiteness of the Slutsky matrix. Numbers in parentheses are standard errors. AIDS is the fully nonlinear PIGLOG model estimated by iterated SUR. 
Table 7: True and estimated elasticities using the $\mathrm{m}_{4}$ total-expenditure process

\begin{tabular}{|c|c|c|c|c|c|c|c|c|c|c|c|c|c|}
\hline \multirow{3}{*}{ Models } & \multicolumn{6}{|c|}{ Elasticities of substitution } & \multicolumn{6}{|c|}{ Income elasticities } & \multirow{3}{*}{$\begin{array}{c}\text { Regulation } \\
\text { condition }\end{array}$} \\
\hline & \multicolumn{3}{|c|}{ True values } & \multicolumn{3}{|c|}{ Estimated values } & \multicolumn{3}{|c|}{ True values } & \multicolumn{3}{|c|}{ Estimated values } & \\
\hline & $\sigma_{12}$ & $\sigma_{13}$ & $\sigma_{23}$ & $\tilde{\sigma}_{12}$ & $\tilde{\sigma}_{13}$ & $\tilde{\sigma}_{23}$ & $\eta_{1}$ & $\eta_{2}$ & $\eta_{3}$ & $\tilde{\eta}_{1}$ & $\tilde{\eta}_{2}$ & $\tilde{\eta}_{3}$ & \\
\hline $\begin{array}{l}\text { Case 1: } \\
\quad \text { Rotterdam }\end{array}$ & \multirow[b]{2}{*}{1.22} & \multirow[b]{2}{*}{.85} & \multirow[b]{2}{*}{.85} & $\begin{array}{c}2.27 \\
(0.04) \\
\end{array}$ & $\begin{array}{c}0.42 \\
(0.08)\end{array}$ & $\begin{array}{c}1.17 \\
(0.05)\end{array}$ & \multirow[b]{2}{*}{.87} & \multirow[b]{2}{*}{.88} & \multirow[b]{2}{*}{1.46} & $\begin{array}{c}1.38 \\
(0.01)\end{array}$ & $\begin{array}{c}0.81 \\
(0.01)\end{array}$ & $\begin{array}{c}0.75 \\
(0.01)\end{array}$ & 0.62 \\
\hline AIDS & & & & $\begin{array}{l}1.89 \\
(.03)\end{array}$ & $\begin{array}{l}.26 \\
(.04)\end{array}$ & $\begin{array}{l}1.44 \\
(.03)\end{array}$ & & & & $\begin{array}{l}1.35 \\
(.01)\end{array}$ & $\begin{array}{c}.81 \\
(.00)\end{array}$ & $\begin{array}{c}.79 \\
(.01)\end{array}$ & 0.20 \\
\hline $\begin{array}{l}\text { Case 2: } \\
\quad \text { Rotterdam }\end{array}$ & \multirow[b]{2}{*}{2.98} & \multirow[b]{2}{*}{.67} & \multirow[b]{2}{*}{.68} & $\begin{array}{c}3.73 \\
(0.07)\end{array}$ & $\begin{array}{c}0.30 \\
(0.04)\end{array}$ & $\begin{array}{c}1.13 \\
(0.03)\end{array}$ & \multirow[b]{2}{*}{1.25} & \multirow[b]{2}{*}{1.27} & \multirow[b]{2}{*}{.68} & $\begin{array}{c}1.75 \\
(0.01)\end{array}$ & $\begin{array}{c}1.32 \\
(0.01)\end{array}$ & $\begin{array}{c}0.37 \\
(0.00)\end{array}$ & 0.64 \\
\hline AIDS & & & & $\begin{array}{l}3.12 \\
(.06)\end{array}$ & $\begin{array}{l}-.38 \\
(.03)\end{array}$ & $\begin{array}{l}1.63 \\
(.02)\end{array}$ & & & & $\begin{array}{l}1.69 \\
(.01)\end{array}$ & $\begin{array}{l}1.29 \\
(.01)\end{array}$ & $\begin{array}{c}.43 \\
(.00)\end{array}$ & 0.68 \\
\hline $\begin{array}{l}\text { Case 3: } \\
\quad \text { Rotterdam }\end{array}$ & \multirow[b]{2}{*}{1.82} & \multirow[b]{2}{*}{1.29} & \multirow[b]{2}{*}{1.27} & $\begin{array}{c}2.82 \\
(0.28)\end{array}$ & $\begin{array}{c}.92 \\
(0.09)\end{array}$ & $\begin{array}{c}1.89 \\
(0.09)\end{array}$ & \multirow[b]{2}{*}{1.33} & \multirow[b]{2}{*}{1.30} & \multirow[b]{2}{*}{.89} & $\begin{array}{c}1.46 \\
(0.02)\end{array}$ & $\begin{array}{c}3.03 \\
(0.02)\end{array}$ & $\begin{array}{c}0.57 \\
(0.00)\end{array}$ & 0.53 \\
\hline AIDS & & & & $\begin{array}{l}1.46 \\
(.11)\end{array}$ & $\begin{array}{l}1.07 \\
(.04)\end{array}$ & $\begin{array}{l}2.86 \\
(.03)\end{array}$ & & & & $\begin{array}{l}1.41 \\
(.01)\end{array}$ & $\begin{array}{l}2.62 \\
(.02)\end{array}$ & $\begin{array}{c}.64 \\
(.00)\end{array}$ & 0.79 \\
\hline $\begin{array}{l}\text { Case 4: } \\
\quad \text { Rotterdam }\end{array}$ & \multirow[b]{2}{*}{.52} & \multirow[b]{2}{*}{1.20} & \multirow[b]{2}{*}{.91} & $\begin{array}{c}1.54 \\
(0.06)\end{array}$ & $\begin{array}{c}.69 \\
(0.08)\end{array}$ & $\begin{array}{c}1.06 \\
(0.07)\end{array}$ & \multirow[b]{2}{*}{.82} & \multirow[b]{2}{*}{.62} & \multirow[b]{2}{*}{1.40} & $\begin{array}{c}.96 \\
(0.01)\end{array}$ & $\begin{array}{c}1.41 \\
(0.01)\end{array}$ & $\begin{array}{c}0.70 \\
(0.01)\end{array}$ & 0.59 \\
\hline AIDS & & & & $\begin{array}{l}1.26 \\
(.02)\end{array}$ & $\begin{array}{l}.96 \\
(.03)\end{array}$ & $\begin{array}{l}1.74 \\
(.02)\end{array}$ & & & & $\begin{array}{l}.95 \\
(.01)\end{array}$ & $\begin{array}{l}1.36 \\
(.01)\end{array}$ & $\begin{array}{l}.75 \\
(.00)\end{array}$ & 0.93 \\
\hline $\begin{array}{l}\text { Case 5: } \\
\text { Rotterdam }\end{array}$ & & & & $\begin{array}{c}1.87 \\
(0.26)\end{array}$ & $\begin{array}{c}3.01 \\
(0.17)\end{array}$ & $\begin{array}{c}1.82 \\
(0.09)\end{array}$ & & & & $\begin{array}{c}.30 \\
(0.01)\end{array}$ & $\begin{array}{c}.94 \\
(0.01)\end{array}$ & $\begin{array}{c}1.09 \\
(0.00)\end{array}$ & 0.59 \\
\hline AIDS & 1.90 & 1.33 & 1.28 & $\begin{array}{l}4.77 \\
(.07)\end{array}$ & $\begin{array}{l}1.69 \\
(.05)\end{array}$ & $\begin{array}{l}1.49 \\
(.02)\end{array}$ & 1.04 & 1.00 & 1.00 & $\begin{array}{l}.30 \\
(.01)\end{array}$ & $\begin{array}{l}.95 \\
(.01)\end{array}$ & $\begin{array}{l}1.09 \\
(.00)\end{array}$ & 0.09 \\
\hline $\begin{array}{l}\text { Case 6: } \\
\quad \text { Rotterdam }\end{array}$ & & & & $\begin{array}{c}1.33 \\
(0.05)\end{array}$ & $\begin{array}{c}.95 \\
(0.06)\end{array}$ & $\begin{array}{c}.98 \\
(0.04)\end{array}$ & & & & $\begin{array}{c}1.02 \\
(0.01)\end{array}$ & $\begin{array}{c}0.88 \\
(0.01)\end{array}$ & $\begin{array}{c}1.08 \\
(0.01)\end{array}$ & 0.64 \\
\hline AIDS & .67 & .76 & .68 & $\begin{array}{l}1.27 \\
(.02)\end{array}$ & $\begin{array}{l}1.00 \\
(.03)\end{array}$ & $\begin{array}{l}1.01 \\
(.02)\end{array}$ & .89 & .80 & 1.21 & $\begin{array}{l}1.01 \\
(.01)\end{array}$ & $\begin{array}{c}.88 \\
(.01)\end{array}$ & $\begin{array}{l}1.09 \\
(.00)\end{array}$ & 0.56 \\
\hline $\begin{array}{l}\text { Case 7: } \\
\text { Rotterdam }\end{array}$ & & & & $\begin{array}{c}5.58 \\
(0.15)\end{array}$ & $\begin{array}{c}0.97 \\
(0.06)\end{array}$ & $\begin{array}{c}1.07 \\
(0.03)\end{array}$ & & & & $\begin{array}{c}0.28 \\
(0.01)\end{array}$ & $\begin{array}{c}2.06 \\
(0.01)\end{array}$ & $\begin{array}{c}.55 \\
(0.00)\end{array}$ & 0.81 \\
\hline AIDS & 3.20 & .76 & .76 & $\begin{array}{l}5.24 \\
(.09)\end{array}$ & $\begin{array}{l}1.19 \\
(.04)\end{array}$ & $\begin{array}{l}.80 \\
(.01)\end{array}$ & 1.44 & 1.44 & .78 & $\begin{array}{c}.35 \\
(.01)\end{array}$ & $\begin{array}{l}1.99 \\
(.01)\end{array}$ & $\begin{array}{c}.58 \\
(.00)\end{array}$ & 0.85 \\
\hline $\begin{array}{l}\text { Case } 8: \\
\quad \text { Rotterdam }\end{array}$ & & & & $\begin{array}{l}-1.38 \\
(0.68)\end{array}$ & $\begin{array}{c}4.02 \\
(0.32)\end{array}$ & $\begin{array}{c}1.50 \\
(0.19)\end{array}$ & & & & $\begin{array}{c}0.18 \\
(0.01)\end{array}$ & $\begin{array}{l}2.59 \\
(0.01\end{array}$ & $\begin{array}{c}0.43 \\
(0.00)\end{array}$ & 0.50 \\
\hline AIDS & 3.22 & 2.22 & 2.17 & $\begin{array}{l}3.39 \\
(.13)\end{array}$ & $\begin{array}{l}2.40 \\
(.09)\end{array}$ & $\begin{array}{l}3.73 \\
(.03)\end{array}$ & 1.45 & 1.41 & .82 & $\begin{array}{l}.20 \\
(.01)\end{array}$ & $\begin{array}{l}2.50 \\
(.01)\end{array}$ & $\begin{array}{l}.46 \\
(.00)\end{array}$ & 0.68 \\
\hline $\begin{array}{l}\text { Case 9: } \\
\text { Rotterdam }\end{array}$ & & & & $\begin{array}{l}-10.26 \\
(1.58)\end{array}$ & $\begin{array}{c}8.14 \\
(0.57)\end{array}$ & $\begin{array}{c}4.39 \\
(0.48)\end{array}$ & & & & $\begin{array}{c}0.16 \\
(0.01)\end{array}$ & $\begin{array}{c}2.01 \\
(0.01)\end{array}$ & $\begin{array}{c}0.72 \\
(0.00)\end{array}$ & 0.43 \\
\hline AIDS & 4.13 & 4.65 & 4.54 & $\begin{array}{l}.18 \\
(.32)\end{array}$ & $\begin{array}{l}4.83 \\
(.16)\end{array}$ & $\begin{array}{l}6.82 \\
(.08)\end{array}$ & 1.45 & 1.41 & .82 & $\begin{array}{l}.17 \\
(.01)\end{array}$ & $\begin{array}{l}1.91 \\
(.01)\end{array}$ & $\begin{array}{l}.75 \\
(.00)\end{array}$ & 0.06 \\
\hline
\end{tabular}

Note: The regularity condition is the percent of non-violations of negative semi-definiteness of the Slutsky matrix. Numbers in parentheses are standard errors. AIDS is the fully nonlinear PIGLOG model estimated by iterated SUR. 
Table 8: True and estimated elasticities using the $m_{5}$ total-expenditure process

\begin{tabular}{|c|c|c|c|c|c|c|c|c|c|c|c|c|c|}
\hline \multirow{3}{*}{ Models } & \multicolumn{6}{|c|}{$\begin{array}{c}\text { Elasticities of substitution } \\
\end{array}$} & \multicolumn{6}{|c|}{ Income elasticities } & \multirow{3}{*}{$\begin{array}{c}\text { Regulation } \\
\text { condition }\end{array}$} \\
\hline & \multicolumn{3}{|c|}{ True values } & \multicolumn{3}{|c|}{ Estimated values } & \multicolumn{3}{|c|}{ True values } & \multicolumn{3}{|c|}{ Estimated values } & \\
\hline & $\sigma_{12}$ & $\sigma_{13}$ & $\sigma_{23}$ & $\tilde{\sigma}_{12}$ & $\tilde{\sigma}_{13}$ & $\tilde{\sigma}_{23}$ & $\eta_{1}$ & $\eta_{2}$ & $\eta_{3}$ & $\tilde{\eta}_{1}$ & $\tilde{\eta}_{2}$ & $\tilde{\eta}_{3}$ & \\
\hline $\begin{array}{l}\text { Case 1: } \\
\text { Rotterdam }\end{array}$ & \multirow[b]{2}{*}{1.22} & \multirow[b]{2}{*}{.85} & \multirow[b]{2}{*}{.85} & $\begin{array}{c}2.30 \\
(0.05) \\
\end{array}$ & $\begin{array}{c}0.42 \\
(0.10) \\
\end{array}$ & $\begin{array}{c}1.18 \\
(0.06) \\
\end{array}$ & \multirow[b]{2}{*}{.87} & \multirow[b]{2}{*}{.88} & \multirow[b]{2}{*}{1.46} & $\begin{array}{c}1.39 \\
(0.01) \\
\end{array}$ & $\begin{array}{c}0.81 \\
(0.01) \\
\end{array}$ & $\begin{array}{c}0.74 \\
(0.01) \\
\end{array}$ & 0.53 \\
\hline AIDS & & & & $\begin{array}{l}1.89 \\
(.03) \\
\end{array}$ & $\begin{array}{c}.23 \\
(.05) \\
\end{array}$ & $\begin{array}{l}1.47 \\
(.03) \\
\end{array}$ & & & & $\begin{array}{l}1.37 \\
(.01) \\
\end{array}$ & $\begin{array}{c}.80 \\
(.00) \\
\end{array}$ & $\begin{array}{l}.76 \\
(.01) \\
\end{array}$ & 0.19 \\
\hline $\begin{array}{l}\text { Case 2: } \\
\quad \text { Rotterdam }\end{array}$ & \multirow[b]{2}{*}{2.98} & \multirow[b]{2}{*}{.67} & \multirow[b]{2}{*}{.68} & $\begin{array}{c}3.80 \\
(0.12)\end{array}$ & $\begin{array}{c}0.28 \\
(0.06)\end{array}$ & $\begin{array}{c}1.14 \\
(0.05)\end{array}$ & \multirow[b]{2}{*}{1.25} & \multirow[b]{2}{*}{1.27} & \multirow[b]{2}{*}{.68} & $\begin{array}{c}1.78 \\
(0.01)\end{array}$ & $\begin{array}{c}1.32 \\
(0.01)\end{array}$ & $\begin{array}{c}0.35 \\
(0.00)\end{array}$ & 0.64 \\
\hline AIDS & & & & $\begin{array}{l}3.19 \\
(.08) \\
\end{array}$ & $\begin{array}{l}-.53 \\
(.04) \\
\end{array}$ & $\begin{array}{l}1.65 \\
(.03) \\
\end{array}$ & & & & $\begin{array}{l}1.73 \\
(.01) \\
\end{array}$ & $\begin{array}{l}1.31 \\
(.01) \\
\end{array}$ & $\begin{array}{c}.39 \\
(.00) \\
\end{array}$ & 0.59 \\
\hline $\begin{array}{l}\text { Case 3: } \\
\text { Rotterdam } \\
\end{array}$ & \multirow[b]{2}{*}{1.82} & \multirow[b]{2}{*}{1.29} & \multirow[b]{2}{*}{1.27} & $\begin{array}{c}2.94 \\
(0.37) \\
\end{array}$ & $\begin{array}{c}90 \\
(0.11) \\
\end{array}$ & $\begin{array}{c}1.93 \\
(0.12) \\
\end{array}$ & \multirow[b]{2}{*}{1.33} & \multirow[b]{2}{*}{1.30} & \multirow[b]{2}{*}{.89} & $\begin{array}{c}1.48 \\
(0.02) \\
\end{array}$ & $\begin{array}{c}3.15 \\
(0.02) \\
\end{array}$ & $\begin{array}{c}0.54 \\
(0.00) \\
\end{array}$ & 0.46 \\
\hline AIDS & & & & $\begin{array}{l}1.46 \\
(.13) \\
\end{array}$ & $\begin{array}{l}1.04 \\
(.05) \\
\end{array}$ & $\begin{array}{l}3.00 \\
(.03) \\
\end{array}$ & & & & $\begin{array}{l}1.45 \\
(.01)\end{array}$ & $\begin{array}{l}2.76 \\
(.02)\end{array}$ & $\begin{array}{l}.61 \\
(.00)\end{array}$ & 0.72 \\
\hline $\begin{array}{l}\text { Case 4: } \\
\quad \text { Rotterdam } \\
\end{array}$ & \multirow[b]{2}{*}{.52} & \multirow[b]{2}{*}{1.20} & \multirow[b]{2}{*}{.91} & $\begin{array}{c}1.59 \\
(0.08) \\
\end{array}$ & $\begin{array}{c}.65 \\
(0.10) \\
\end{array}$ & $\begin{array}{c}1.03 \\
(0.09) \\
\end{array}$ & \multirow[b]{2}{*}{.82} & \multirow[b]{2}{*}{.62} & \multirow[b]{2}{*}{1.40} & $\begin{array}{c}.96 \\
(0.01) \\
\end{array}$ & $\begin{array}{c}1.44 \\
(0.01)\end{array}$ & $\begin{array}{c}0.68 \\
(0.01)\end{array}$ & 0.51 \\
\hline AIDS & & & & $\begin{array}{l}1.29 \\
(.03)\end{array}$ & $\begin{array}{c}.93 \\
(.04)\end{array}$ & $\begin{array}{l}1.78 \\
(.02)\end{array}$ & & & & $\begin{array}{l}.95 \\
(.01)\end{array}$ & $\begin{array}{l}1.40 \\
(.01)\end{array}$ & $\begin{array}{l}.71 \\
(.00)\end{array}$ & 0.87 \\
\hline $\begin{array}{l}\text { Case 5: } \\
\text { Rotterdam }\end{array}$ & & & & $\begin{array}{c}1.87 \\
(0.33) \\
\end{array}$ & $\begin{array}{c}3.11 \\
(0.21) \\
\end{array}$ & $\begin{array}{c}1.83 \\
(0.11) \\
\end{array}$ & & & & $\begin{array}{c}.29 \\
(0.01) \\
\end{array}$ & $\begin{array}{c}.95 \\
(0.01) \\
\end{array}$ & $\begin{array}{c}1.09 \\
(0.00) \\
\end{array}$ & 0.51 \\
\hline AIDS & 1.90 & 1.33 & 1.28 & $\begin{array}{l}4.86 \\
(.08) \\
\end{array}$ & $\begin{array}{l}1.71 \\
(.07) \\
\end{array}$ & $\begin{array}{l}1.50 \\
(.02) \\
\end{array}$ & 1.04 & 1.00 & 1.00 & $\begin{array}{l}.26 \\
(.01) \\
\end{array}$ & $\begin{array}{c}.95 \\
(.01) \\
\end{array}$ & $\begin{array}{l}1.09 \\
(.00) \\
\end{array}$ & 0.12 \\
\hline $\begin{array}{l}\text { Case } 6: \\
\text { Rotterdam } \\
\end{array}$ & & & & $\begin{array}{c}1.34 \\
(0.06) \\
\end{array}$ & $\begin{array}{c}.95 \\
(0.07) \\
\end{array}$ & $\begin{array}{c}.98 \\
(0.05) \\
\end{array}$ & & & & $\begin{array}{c}1.03 \\
(0.01) \\
\end{array}$ & $\begin{array}{c}0.88 \\
(0.01) \\
\end{array}$ & $\begin{array}{c}1.08 \\
(0.01) \\
\end{array}$ & 0.54 \\
\hline AIDS & .67 & .76 & .68 & $\begin{array}{l}1.28 \\
(.03)\end{array}$ & $\begin{array}{l}1.01 \\
(.04)\end{array}$ & $\begin{array}{l}1.02 \\
(.02)\end{array}$ & .89 & .80 & 1.21 & $\begin{array}{l}1.01 \\
(.01)\end{array}$ & $\begin{array}{c}.88 \\
(.01)\end{array}$ & $\begin{array}{l}1.09 \\
(.00)\end{array}$ & 0.51 \\
\hline $\begin{array}{l}\text { Case 7: } \\
\quad \text { Rotterdam } \\
\end{array}$ & & & & $\begin{array}{c}5.67 \\
(0.20) \\
\end{array}$ & $\begin{array}{c}0.94 \\
(0.09) \\
\end{array}$ & $\begin{array}{c}1.08 \\
(0.03) \\
\end{array}$ & & & & $\begin{array}{c}0.26 \\
(0.02) \\
\end{array}$ & $\begin{array}{c}2.09 \\
(0.01) \\
\end{array}$ & $\begin{array}{c}.54 \\
(0.00) \\
\end{array}$ & 0.69 \\
\hline AIDS & 3.20 & .76 & .76 & $\begin{array}{l}5.18 \\
(.12)\end{array}$ & $\begin{array}{l}1.24 \\
(.05)\end{array}$ & $\begin{array}{l}.74 \\
(.02)\end{array}$ & 1.44 & 1.44 & .78 & $\begin{array}{l}.31 \\
(.01)\end{array}$ & $\begin{array}{l}2.04 \\
(.01)\end{array}$ & $\begin{array}{c}.56 \\
(.00)\end{array}$ & 0.79 \\
\hline $\begin{array}{l}\text { Case 8: } \\
\quad \text { Rotterdam }\end{array}$ & & & & $\begin{array}{l}-1.72 \\
(0.88)\end{array}$ & $\begin{array}{c}4.15 \\
(0.41)\end{array}$ & $\begin{array}{c}1.53 \\
(0.24)\end{array}$ & & & & $\begin{array}{c}0.16 \\
(0.01)\end{array}$ & $\begin{array}{l}2.62 \\
(0.01\end{array}$ & $\begin{array}{c}0.42 \\
(0.00)\end{array}$ & 0.34 \\
\hline AIDS & 3.22 & 2.22 & 2.17 & $\begin{array}{l}3.45 \\
(.16) \\
\end{array}$ & $\begin{array}{l}2.41 \\
(.12)\end{array}$ & $\begin{array}{l}3.79 \\
(.04)\end{array}$ & 1.45 & 1.41 & .82 & $\begin{array}{l}.16 \\
(.01)\end{array}$ & $\begin{array}{l}2.58 \\
(.01) \\
\end{array}$ & $\begin{array}{c}.43 \\
(.00)\end{array}$ & 0.67 \\
\hline $\begin{array}{l}\text { Case 9: } \\
\text { Rotterdam }\end{array}$ & & & & $\begin{array}{l}-9.65 \\
(2.05)\end{array}$ & $\begin{array}{c}7.98 \\
(0.73)\end{array}$ & $\begin{array}{c}4.09 \\
(0.61)\end{array}$ & & & & $\begin{array}{c}0.13 \\
(0.01)\end{array}$ & $\begin{array}{c}2.05 \\
(0.01)\end{array}$ & $\begin{array}{c}0.71 \\
(0.00)\end{array}$ & 0.36 \\
\hline AIDS & 4.13 & 4.65 & 4.54 & $\begin{array}{l}.31 \\
(.41) \\
\end{array}$ & $\begin{array}{l}4.86 \\
(.21) \\
\end{array}$ & $\begin{array}{l}6.95 \\
(.10) \\
\end{array}$ & 1.45 & 1.41 & .82 & $\begin{array}{l}.12 \\
(.01)\end{array}$ & $\begin{array}{l}1.96 \\
(.01) \\
\end{array}$ & $\begin{array}{l}.74 \\
(.00) \\
\end{array}$ & 0.07 \\
\hline
\end{tabular}

Note: The regularity condition is the percent of non-violations of negative semi-definiteness of the Slutsky matrix. Numbers in parentheses are standard errors. AIDS is the fully nonlinear PIGLOG model estimated by iterated SUR. 
Table 9a: Case 1 FIML estimation of LA-AIDS using four price indices

\begin{tabular}{|c|c|c|c|c|c|c|c|c|c|c|c|c|}
\hline \multirow[b]{3}{*}{ Price Index } & \multicolumn{6}{|c|}{ Elasticities of substitution } & \multicolumn{6}{|c|}{ Income elasticities } \\
\hline & \multicolumn{3}{|c|}{ True values } & \multicolumn{3}{|c|}{ Estimated values } & \multicolumn{3}{|c|}{ True values } & \multicolumn{3}{|c|}{ Estimated values } \\
\hline & $\sigma_{12}$ & $\sigma_{13}$ & $\sigma_{23}$ & $\tilde{\sigma}_{12}$ & $\tilde{\sigma}_{13}$ & $\tilde{\sigma}_{23}$ & $\eta_{1}$ & $\eta_{2}$ & $\eta_{3}$ & $\tilde{\eta}_{1}$ & $\tilde{\eta}_{2}$ & $\tilde{\eta}_{3}$ \\
\hline Quasi-Törnqvist & \multirow{4}{*}{1.22} & \multirow{4}{*}{.85} & \multirow{4}{*}{.85} & $\begin{array}{c}3.94 \\
(0.02) \\
\end{array}$ & $\begin{array}{c}-.51 \\
(0.02) \\
\end{array}$ & $\begin{array}{c}-37 \\
(0.02) \\
\end{array}$ & \multirow{4}{*}{.87} & \multirow{4}{*}{.88} & \multirow{4}{*}{1.46} & $\begin{array}{c}1.10 \\
(0.00) \\
\end{array}$ & $\begin{array}{c}0.83 \\
(0.00) \\
\end{array}$ & $\begin{array}{c}1.16 \\
(0.00) \\
\end{array}$ \\
\hline Quasi-Paasche & & & & $\begin{array}{c}3.92 \\
(0.02)\end{array}$ & $\begin{array}{c}-.52 \\
(0.02)\end{array}$ & $\begin{array}{c}-.36 \\
(0.02)\end{array}$ & & & & $\begin{array}{c}1.06 \\
(0.00)\end{array}$ & $\begin{array}{c}0.86 \\
(0.00)\end{array}$ & $\begin{array}{c}1.16 \\
(0.00)\end{array}$ \\
\hline Quasi-Laspeyres & & & & $\begin{array}{c}3.95 \\
(0.02)\end{array}$ & $\begin{array}{c}-.54 \\
(0.02)\end{array}$ & $\begin{array}{c}-.34 \\
(0.02)\end{array}$ & & & & $\begin{array}{c}1.14 \\
(0.00)\end{array}$ & $\begin{array}{c}0.80 \\
(0.00)\end{array}$ & $\begin{array}{c}1.16 \\
(0.00)\end{array}$ \\
\hline Stone & & & & $\begin{array}{c}3.87 \\
(0.02)\end{array}$ & $\begin{array}{c}-.72 \\
(0.03)\end{array}$ & $\begin{array}{c}-.37 \\
(0.02)\end{array}$ & & & & $\begin{array}{c}1.04 \\
(0.00)\end{array}$ & $\begin{array}{c}0.82 \\
(0.00)\end{array}$ & $\begin{array}{c}1.28 \\
(0.00)\end{array}$ \\
\hline
\end{tabular}

Note: Standard errors are in parentheses. Replications $=1,000$.

Table 9b: Case 2 FIML estimation of LA-AIDS using four price indices

\begin{tabular}{|c|c|c|c|c|c|c|c|c|c|c|c|c|}
\hline \multirow{3}{*}{ Price Index } & \multicolumn{6}{|c|}{ Elasticities of substitution } & \multicolumn{6}{|c|}{ Income elasticities } \\
\hline & \multicolumn{3}{|c|}{ True values } & \multicolumn{3}{|c|}{ Estimated values } & \multicolumn{3}{|c|}{ True values } & \multicolumn{3}{|c|}{ Estimated values } \\
\hline & $\sigma_{12}$ & $\sigma_{13}$ & $\sigma_{23}$ & $\tilde{\sigma}_{12}$ & $\tilde{\sigma}_{13}$ & $\tilde{\sigma}_{23}$ & $\eta_{1}$ & $\eta_{2}$ & $\eta_{3}$ & $\tilde{\eta}_{1}$ & $\tilde{\eta}_{2}$ & $\tilde{\eta}_{3}$ \\
\hline Quasi-Törnqvist & \multirow{4}{*}{2.98} & \multirow{4}{*}{.67} & \multirow{4}{*}{.68} & $\begin{array}{l}5.50 \\
(.04)\end{array}$ & $\begin{array}{c}-.57 \\
(0.02)\end{array}$ & $\begin{array}{c}.97 \\
(0.02)\end{array}$ & \multirow{4}{*}{1.25} & \multirow{4}{*}{1.27} & \multirow{4}{*}{.68} & $\begin{array}{c}0.81 \\
(0.01)\end{array}$ & $\begin{array}{c}0.91 \\
(0.01)\end{array}$ & $\begin{array}{c}1.17 \\
(0.00)\end{array}$ \\
\hline Quasi-Paasche & & & & $\begin{array}{l}5.55 \\
(.04)\end{array}$ & $\begin{array}{c}-.64 \\
(0.02)\end{array}$ & $\begin{array}{c}1.03 \\
(0.02)\end{array}$ & & & & $\begin{array}{c}.76 \\
(0.01)\end{array}$ & $\begin{array}{c}0.95 \\
(0.01)\end{array}$ & $\begin{array}{c}1.17 \\
(0.00) \\
\end{array}$ \\
\hline Quasi-Laspeyres & & & & $\begin{array}{l}5.43 \\
(.04)\end{array}$ & $\begin{array}{c}-.51 \\
(0.02)\end{array}$ & $\begin{array}{c}0.91 \\
(0.01)\end{array}$ & & & & $\begin{array}{c}.86 \\
(0.01)\end{array}$ & $\begin{array}{c}0.86 \\
(0.01)\end{array}$ & $\begin{array}{c}1.17 \\
(0.00)\end{array}$ \\
\hline Stone & & & & $\begin{array}{l}5.57 \\
(.04)\end{array}$ & $\begin{array}{c}-.69 \\
(0.02)\end{array}$ & $\begin{array}{c}0.68 \\
(0.02)\end{array}$ & & & & $\begin{array}{c}.70 \\
(0.01)\end{array}$ & $\begin{array}{c}0.82 \\
(0.01)\end{array}$ & $\begin{array}{c}1.29 \\
(0.00)\end{array}$ \\
\hline
\end{tabular}

Note: Standard errors are in parentheses. Replications $=1,000$.

Table 9c: Case 3 FIML estimation of LA-AIDS using four price indices

\begin{tabular}{|c|c|c|c|c|c|c|c|c|c|c|c|c|}
\hline \multirow{3}{*}{ Price Index } & \multicolumn{6}{|c|}{ Elasticities of substitution } & \multicolumn{6}{|c|}{ Income elasticities } \\
\hline & \multicolumn{3}{|c|}{ True values } & \multicolumn{3}{|c|}{ Estimated values } & \multicolumn{3}{|c|}{ True values } & \multicolumn{3}{|c|}{ Estimated values } \\
\hline & $\sigma_{12}$ & $\sigma_{13}$ & $\sigma_{23}$ & $\tilde{\sigma}_{12}$ & $\tilde{\sigma}_{13}$ & $\tilde{\sigma}_{23}$ & $\eta_{1}$ & $\eta_{2}$ & $\eta_{3}$ & $\tilde{\eta}_{1}$ & $\tilde{\eta}_{2}$ & $\tilde{\eta}_{3}$ \\
\hline Quasi-Törnqvist & \multirow{4}{*}{1.82} & \multirow{4}{*}{1.29} & \multirow{4}{*}{1.27} & $\begin{array}{l}9.70 \\
(.06)\end{array}$ & $\begin{array}{c}-.79 \\
(0.01)\end{array}$ & $\begin{array}{c}.05 \\
(0.01)\end{array}$ & \multirow{4}{*}{1.33} & \multirow{4}{*}{1.3} & \multirow{4}{*}{.89} & $\begin{array}{c}0.57 \\
(0.01)\end{array}$ & $\begin{array}{c}0.9 \\
(0.01)\end{array}$ & $\begin{array}{r}1.09 \\
(0.00)\end{array}$ \\
\hline Quasi-Paasche & & & & $\begin{array}{l}9.55 \\
(.06)\end{array}$ & $\begin{array}{c}-.73 \\
(0.01)\end{array}$ & $\begin{array}{c}-.01 \\
(0.01)\end{array}$ & & & & $\begin{array}{c}0.62 \\
(0.01)\end{array}$ & $\begin{array}{c}0.86 \\
(0.01)\end{array}$ & $\begin{array}{c}1.09 \\
(0.00)\end{array}$ \\
\hline Quasi-Laspeyres & & & & $\begin{array}{l}9.84 \\
(.06)\end{array}$ & $\begin{array}{c}-.86 \\
(0.01)\end{array}$ & $\begin{array}{c}.11 \\
(0.01)\end{array}$ & & & & $\begin{array}{c}0.52 \\
(0.01)\end{array}$ & $\begin{array}{c}0.95 \\
(0.01)\end{array}$ & $\begin{array}{c}1.09 \\
(0.00)\end{array}$ \\
\hline Stone & & & & $\begin{array}{l}8.80 \\
(.06)\end{array}$ & $\begin{array}{c}-.43 \\
(0.01)\end{array}$ & $\begin{array}{c}-.59 \\
(0.01)\end{array}$ & & & & $\begin{array}{c}0.64 \\
(0.01)\end{array}$ & $\begin{array}{c}0.45 \\
(0.01)\end{array}$ & $\begin{array}{c}1.16 \\
(0.00)\end{array}$ \\
\hline
\end{tabular}

Note: Standard errors are in parentheses. Replications $=1,000$. 
Table 9d: Case 4 FIML estimation of LA-AIDS using four price indices

\begin{tabular}{|c|c|c|c|c|c|c|c|c|c|c|c|c|}
\hline \multirow{3}{*}{ Price Index } & \multicolumn{6}{|c|}{ Elasticities of substitution } & \multicolumn{6}{|c|}{ Income elasticities } \\
\hline & \multicolumn{3}{|c|}{ True values } & \multicolumn{3}{|c|}{ Estimated values } & \multicolumn{3}{|c|}{ True values } & \multicolumn{3}{|c|}{ Estimated values } \\
\hline & $\sigma_{12}$ & $\sigma_{13}$ & $\sigma_{23}$ & $\tilde{\sigma}_{12}$ & $\tilde{\sigma}_{13}$ & $\tilde{\sigma}_{23}$ & $\eta_{1}$ & $\eta_{2}$ & $\eta_{3}$ & $\tilde{\eta}_{1}$ & $\tilde{\eta}_{2}$ & $\tilde{\eta}_{3}$ \\
\hline Quasi-Törnqvist & \multirow{4}{*}{.52} & \multirow{4}{*}{1.20} & \multirow{4}{*}{.91} & $\begin{array}{c}3.23 \\
(0.01) \\
\end{array}$ & $\begin{array}{c}-.88 \\
(0.01)\end{array}$ & $\begin{array}{c}1.15 \\
(0.01) \\
\end{array}$ & \multirow{4}{*}{.82} & \multirow{4}{*}{.62} & \multirow{4}{*}{1.4} & $\begin{array}{c}0.84 \\
(0.01) \\
\end{array}$ & $\begin{array}{c}1.01 \\
(0.00) \\
\end{array}$ & $\begin{array}{c}1.08 \\
(0.00) \\
\end{array}$ \\
\hline Quasi-Paasche & & & & $\begin{array}{c}3.32 \\
(0.01)\end{array}$ & $\begin{array}{c}-84 \\
(0.01)\end{array}$ & $\begin{array}{c}1.13 \\
(0.01)\end{array}$ & & & & $\begin{array}{c}0.88 \\
(0.01)\end{array}$ & $\begin{array}{c}.99 \\
(0.00)\end{array}$ & $\begin{array}{c}1.08 \\
(0.00)\end{array}$ \\
\hline Quasi-Laspeyres & & & & $\begin{array}{c}3.33 \\
(0.01) \\
\end{array}$ & $\begin{array}{c}.91 \\
(0.01) \\
\end{array}$ & $\begin{array}{c}1.27 \\
(0.01)\end{array}$ & & & & $\begin{array}{c}0.81 \\
(0.01) \\
\end{array}$ & $\begin{array}{c}1.03 \\
(0.00)\end{array}$ & $\begin{array}{c}1.08 \\
(0.00) \\
\end{array}$ \\
\hline Stone & & & & $\begin{array}{c}3.26 \\
(0.01)\end{array}$ & $\begin{array}{c}-.71 \\
(0.01)\end{array}$ & $\begin{array}{c}0.95 \\
(0.01)\end{array}$ & & & & $\begin{array}{c}0.93 \\
(0.01)\end{array}$ & $\begin{array}{c}.87 \\
(0.00)\end{array}$ & $\begin{array}{c}1.14 \\
(0.00)\end{array}$ \\
\hline
\end{tabular}

Note: Standard errors are in parentheses. Replications $=1,000$.

Table 9e: Case 5 FIML estimation of LA-AIDS using four price indices

\begin{tabular}{|c|c|c|c|c|c|c|c|c|c|c|c|c|}
\hline \multirow{3}{*}{ Price Index } & \multicolumn{6}{|c|}{ Elasticities of substitution } & \multicolumn{6}{|c|}{ Income elasticities } \\
\hline & \multicolumn{3}{|c|}{ True values } & \multicolumn{3}{|c|}{ Estimated values } & \multicolumn{3}{|c|}{ True values } & \multicolumn{3}{|c|}{ Estimated values } \\
\hline & $\sigma_{12}$ & $\sigma_{13}$ & $\sigma_{23}$ & $\tilde{\sigma}_{12}$ & $\tilde{\sigma}_{13}$ & $\tilde{\sigma}_{23}$ & $\eta_{1}$ & $\eta_{2}$ & $\eta_{3}$ & $\tilde{\eta}_{1}$ & $\tilde{\eta}_{2}$ & $\tilde{\eta}_{3}$ \\
\hline Quasi-Törnqvist & \multirow{4}{*}{1.9} & \multirow{4}{*}{1.33} & \multirow{4}{*}{1.28} & $\begin{array}{l}7.37 \\
(.04)\end{array}$ & $\begin{array}{c}-0.26 \\
(.03)\end{array}$ & $\begin{array}{c}0.28 \\
(0.01)\end{array}$ & \multirow{4}{*}{1.04} & \multirow{4}{*}{1.00} & \multirow{4}{*}{1.00} & $\begin{array}{c}0.50 \\
(0.01)\end{array}$ & $\begin{array}{c}1.01 \\
(0.00)\end{array}$ & $\begin{array}{c}1.04 \\
(0.00)\end{array}$ \\
\hline Quasi-Paasche & & & & $\begin{array}{l}7.53 \\
(.04)\end{array}$ & $\begin{array}{l}-0.43 \\
(.03)\end{array}$ & $\begin{array}{c}0.32 \\
(0.01)\end{array}$ & & & & $\begin{array}{c}0.47 \\
(0.01)\end{array}$ & $\begin{array}{c}1.02 \\
(0.00)\end{array}$ & $\begin{array}{r}1.04 \\
(0.00\end{array}$ \\
\hline Quasi-Laspeyres & & & & $\begin{array}{l}7.21 \\
(.04)\end{array}$ & $\begin{array}{c}-0.10 \\
(.03)\end{array}$ & $\begin{array}{c}0.25 \\
(0.01)\end{array}$ & & & & $\begin{array}{c}0.52 \\
(0.01)\end{array}$ & $\begin{array}{c}1.00 \\
(0.00)\end{array}$ & $\begin{array}{c}1.04 \\
(0.00\end{array}$ \\
\hline Stone & & & & $\begin{array}{l}6.99 \\
(.04)\end{array}$ & $\begin{array}{l}0.07 \\
(.03) \\
\end{array}$ & $\begin{array}{c}0.22 \\
(0.01)\end{array}$ & & & & $\begin{array}{c}0.73 \\
(0.01) \\
\end{array}$ & $\begin{array}{c}.90 \\
(0.00)\end{array}$ & $\begin{array}{r}1.07 \\
(0.00 \\
\end{array}$ \\
\hline
\end{tabular}

Note: Standard errors are in parentheses. Replications $=1,000$.

Table 9f: Case 6 FIML estimation of LA-AIDS using four price indices

\begin{tabular}{|c|c|c|c|c|c|c|c|c|c|c|c|c|}
\hline \multirow{3}{*}{ Price Index } & \multicolumn{6}{|c|}{ Elasticities of substitution } & \multicolumn{6}{|c|}{ Income elasticities } \\
\hline & \multicolumn{3}{|c|}{ True values } & \multicolumn{3}{|c|}{ Estimated values } & \multicolumn{3}{|c|}{ True values } & \multicolumn{3}{|c|}{ Estimated values } \\
\hline & $\sigma_{12}$ & $\sigma_{13}$ & $\sigma_{23}$ & $\tilde{\sigma}_{12}$ & $\tilde{\sigma}_{13}$ & $\tilde{\sigma}_{23}$ & $\eta_{1}$ & $\eta_{2}$ & $\eta_{3}$ & $\tilde{\eta}_{1}$ & $\tilde{\eta}_{2}$ & $\tilde{\eta}_{3}$ \\
\hline Quasi-Törnqvist & \multirow{4}{*}{.67} & \multirow{4}{*}{.76} & \multirow{4}{*}{.68} & $\begin{array}{c}1 \\
3.29 \\
(0.01)\end{array}$ & $\begin{array}{c}-.61 \\
(0.01)\end{array}$ & $\begin{array}{c} \\
1.06 \\
(0.01)\end{array}$ & \multirow{4}{*}{.89} & \multirow{4}{*}{.8} & \multirow{4}{*}{1.21} & $\begin{array}{c}1.00 \\
(0.01)\end{array}$ & $\begin{array}{c}1.94 \\
(0.00)\end{array}$ & $\begin{array}{c}1.04 \\
(0.00)\end{array}$ \\
\hline Quasi-Paasche & & & & $\begin{array}{c}3.33 \\
(0.01)\end{array}$ & $\begin{array}{c}-.66 \\
(0.01)\end{array}$ & $\begin{array}{c}1.11 \\
(0.01)\end{array}$ & & & & $\begin{array}{c}0.94 \\
(0.10)\end{array}$ & $\begin{array}{c}0.99 \\
(0.00)\end{array}$ & $\begin{array}{c}1.04 \\
(0.00)\end{array}$ \\
\hline Quasi-Laspeyres & & & & $\begin{array}{c}3.28 \\
(0.01)\end{array}$ & $\begin{array}{c}.56 \\
(0.01)\end{array}$ & $\begin{array}{c}1.03 \\
(0.01)\end{array}$ & & & & $\begin{array}{c}1.06 \\
(0.00)\end{array}$ & $\begin{array}{c}0.90 \\
(0.00)\end{array}$ & $\begin{array}{c}1.04 \\
(0.00)\end{array}$ \\
\hline Stone & & & & $\begin{array}{c}3.27 \\
(0.01)\end{array}$ & $\begin{array}{c}-.55 \\
(0.01)\end{array}$ & $\begin{array}{c}1.01 \\
(0.01)\end{array}$ & & & & $\begin{array}{c}1.04 \\
(0.01)\end{array}$ & $\begin{array}{c}0.88 \\
(0.00)\end{array}$ & $\begin{array}{c}1.07 \\
(0.00)\end{array}$ \\
\hline
\end{tabular}

Note: Standard errors are in parentheses. Replications $=1,000$. 
Table 9g: Case 7 FIML estimation of LA-AIDS using four price indices

\begin{tabular}{|c|c|c|c|c|c|c|c|c|c|c|c|c|}
\hline \multirow{3}{*}{ Price Index } & \multicolumn{6}{|c|}{ Elasticities of substitution } & \multicolumn{6}{|c|}{ Income elasticities } \\
\hline & \multicolumn{3}{|c|}{ True values } & \multicolumn{3}{|c|}{ Estimated values } & \multicolumn{3}{|c|}{ True values } & \multicolumn{3}{|c|}{ Estimated values } \\
\hline & $\sigma_{12}$ & $\sigma_{13}$ & $\sigma_{23}$ & $\tilde{\sigma}_{12}$ & $\tilde{\sigma}_{13}$ & $\tilde{\sigma}_{23}$ & $\eta_{1}$ & $\eta_{2}$ & $\eta_{3}$ & $\tilde{\eta}_{1}$ & $\tilde{\eta}_{2}$ & $\tilde{\eta}_{3}$ \\
\hline Quasi-Törnqvist & \multirow{4}{*}{3.2} & \multirow{4}{*}{.76} & \multirow{4}{*}{.76} & $\begin{array}{c}6.66 \\
(0.06)\end{array}$ & $\begin{array}{c}0.58 \\
(0.02)\end{array}$ & $\begin{array}{c}-13 \\
(0.00)\end{array}$ & \multirow{4}{*}{1.44} & \multirow{4}{*}{1.44} & \multirow{4}{*}{.78} & $\begin{array}{c}0.37 \\
(0.01) \\
\end{array}$ & $\begin{array}{c}0.78 \\
(0.00)\end{array}$ & $\begin{array}{c}1.13 \\
(0.00)\end{array}$ \\
\hline Quasi-Paasche & & & & $\begin{array}{l}7.04 \\
(.06) \\
\end{array}$ & $\begin{array}{c}0.28 \\
(0.02) \\
\end{array}$ & $\begin{array}{c}-0.09 \\
(0.00)\end{array}$ & & & & $\begin{array}{c}0.30 \\
(0.01)\end{array}$ & $\begin{array}{c}0.79 \\
(0.00) \\
\end{array}$ & $\begin{array}{c}1.13 \\
(0.00)\end{array}$ \\
\hline Quasi-Laspeyres & & & & $\begin{array}{l}6.32 \\
(.06) \\
\end{array}$ & $\begin{array}{c}0.85 \\
(0.02) \\
\end{array}$ & $\begin{array}{c}-0.16 \\
(0.00)\end{array}$ & & & & $\begin{array}{c}0.44 \\
(0.01)\end{array}$ & $\begin{array}{c}0.77 \\
(0.00) \\
\end{array}$ & $\begin{array}{c}1.13 \\
(0.00) \\
\end{array}$ \\
\hline Stone & & & & $\begin{array}{l}5.49 \\
(.06)\end{array}$ & $\begin{array}{c}1.7 \\
(0.02)\end{array}$ & $\begin{array}{c}-.62 \\
(0.00)\end{array}$ & & & & $\begin{array}{c}0.98 \\
(0.01)\end{array}$ & $\begin{array}{c}0.44 \\
(0.00)\end{array}$ & $\begin{array}{c}1.25 \\
(0.00)\end{array}$ \\
\hline
\end{tabular}

Note: Standard errors are in parentheses. Replications $=1,000$.

Table 9h: Case 8 FIML estimation of LA-AIDS using four price indices

\begin{tabular}{|c|c|c|c|c|c|c|c|c|c|c|c|c|}
\hline \multirow{3}{*}{ Price Index } & \multicolumn{6}{|c|}{ Elasticities of substitution } & \multicolumn{6}{|c|}{ Income elasticities } \\
\hline & \multicolumn{3}{|c|}{ True values } & \multicolumn{3}{|c|}{ Estimated values } & \multicolumn{3}{|c|}{ True values } & \multicolumn{3}{|c|}{ Estimated values } \\
\hline & $\sigma_{12}$ & $\sigma_{13}$ & $\sigma_{23}$ & $\tilde{\sigma}_{12}$ & $\tilde{\sigma}_{13}$ & $\tilde{\sigma}_{23}$ & $\eta_{1}$ & $\eta_{2}$ & $\eta_{3}$ & $\tilde{\eta}_{1}$ & $\tilde{\eta}_{2}$ & $\tilde{\eta}_{3}$ \\
\hline Quasi-Törnqvist & \multirow{4}{*}{3.22} & \multirow{4}{*}{2.22} & \multirow{4}{*}{2.17} & $\begin{array}{c}6.49 \\
(0.10)\end{array}$ & $\begin{array}{c}0.29 \\
(0.06)\end{array}$ & $\begin{array}{c}-.27 \\
(0.01)\end{array}$ & \multirow{4}{*}{1.45} & \multirow{4}{*}{1.41} & \multirow{4}{*}{.82} & $\begin{array}{c}0.29 \\
(0.01)\end{array}$ & $\begin{array}{c}0.74 \\
(0.00)\end{array}$ & $\begin{array}{c}1.14 \\
(0.00)\end{array}$ \\
\hline Quasi-Paasche & & & & $\begin{array}{l}6.63 \\
(.10)\end{array}$ & $\begin{array}{l}0.19 \\
(.06)\end{array}$ & $\begin{array}{c}-.26 \\
(0.01)\end{array}$ & & & & $\begin{array}{c}0.29 \\
(0.01)\end{array}$ & $\begin{array}{c}0.74 \\
(0.00)\end{array}$ & $\begin{array}{c}1.13 \\
(0.00)\end{array}$ \\
\hline Quasi-Laspeyres & & & & $\begin{array}{l}6.35 \\
(.09)\end{array}$ & $\begin{array}{l}0.40 \\
(.06)\end{array}$ & $\begin{array}{c}-29 \\
(0.01)\end{array}$ & & & & $\begin{array}{c}0.30 \\
(0.01)\end{array}$ & $\begin{array}{c}0.73 \\
(0.00)\end{array}$ & $\begin{array}{c}1.14 \\
(0.00)\end{array}$ \\
\hline Stone & & & & $\begin{array}{l}(.028 \\
(.10)\end{array}$ & $\begin{array}{l}1.00) \\
1.73 \\
(.06)\end{array}$ & $\begin{array}{l}0.01 \\
-1.06 \\
(0.01)\end{array}$ & & & & $\begin{array}{c}0.01) \\
(0.01)\end{array}$ & $\begin{array}{c}0.24 \\
(0.01)\end{array}$ & $\begin{array}{c}1.30 \\
(0.00)\end{array}$ \\
\hline
\end{tabular}

Note: Standard errors are in parentheses. Replications $=1,000$.

Table 9i: Case 9 FIML estimation of LA-AIDS using four price indices

\begin{tabular}{|c|c|c|c|c|c|c|c|c|c|c|c|c|}
\hline \multirow{3}{*}{ Price Index } & \multicolumn{6}{|c|}{ Elasticities of substitution } & \multicolumn{6}{|c|}{ Income elasticities } \\
\hline & \multicolumn{3}{|c|}{ True values } & \multicolumn{3}{|c|}{ Estimated values } & \multicolumn{3}{|c|}{ True values } & \multicolumn{3}{|c|}{ Estimated values } \\
\hline & $\sigma_{12}$ & $\sigma_{13}$ & $\sigma_{23}$ & $\tilde{\sigma}_{12}$ & $\tilde{\sigma}_{13}$ & $\tilde{\sigma}_{23}$ & $\eta_{1}$ & $\eta_{2}$ & $\eta_{3}$ & $\tilde{\eta}_{1}$ & $\tilde{\eta}_{2}$ & $\tilde{\eta}_{3}$ \\
\hline Quasi-Törnqvist & \multirow{4}{*}{4.13} & \multirow{4}{*}{4.65} & \multirow{4}{*}{4.54} & $\begin{array}{c}12.08 \\
(.20) \\
\end{array}$ & $\begin{array}{l}-1.08 \\
(.10)\end{array}$ & $\begin{array}{l}.19 \\
(.01) \\
\end{array}$ & \multirow{4}{*}{1.46} & \multirow{4}{*}{1.43} & \multirow{4}{*}{0.85} & $\begin{array}{c}0.23 \\
(0.01) \\
\end{array}$ & $\begin{array}{c}0.85 \\
(0.00) \\
\end{array}$ & $\begin{array}{c}1.08 \\
(0.00) \\
\end{array}$ \\
\hline Quasi-Paasche & & & & $\begin{array}{c}12.59 \\
(.20)\end{array}$ & $\begin{array}{l}-1.3 \\
(.10)\end{array}$ & $\begin{array}{l}.15 \\
(.01)\end{array}$ & & & & $\begin{array}{c}0.23 \\
(0.01)\end{array}$ & $\begin{array}{c}0.86 \\
(0.00)\end{array}$ & $\begin{array}{c}1.07 \\
(0.00)\end{array}$ \\
\hline Quasi-Laspeyres & & & & $\begin{array}{c}11.66 \\
(.20)\end{array}$ & $\begin{array}{l}.85 \\
(.09)\end{array}$ & $\begin{array}{c}.23 \\
(.01)\end{array}$ & & & & $\begin{array}{c}0.24 \\
(0.01)\end{array}$ & $\begin{array}{c}0.84 \\
(0.00)\end{array}$ & $\begin{array}{c}1.08 \\
(0.00)\end{array}$ \\
\hline Stone & & & & $\begin{array}{c}15.43 \\
(.21)\end{array}$ & $\begin{array}{l}-3.15 \\
(.10)\end{array}$ & $\begin{array}{c}.08 \\
(.01)\end{array}$ & & & & $\begin{array}{c}0.49 \\
(0.01)\end{array}$ & $\begin{array}{c}0.75 \\
(0.01)\end{array}$ & $\begin{array}{c}1.10 \\
(0.00)\end{array}$ \\
\hline
\end{tabular}

Note: Standard errors are in parentheses. Replications $=1,000$. 